\title{
A REVIEW OF PRACTICES AND TECHNOLOGIES FOR ODOR CONTROL IN SWINE PRODUCTION FACILITIES
}

\author{
Z. Liu, W. Powers, S. Mukhtar
}

\begin{abstract}
The objective of this article is to provide a systematic review on practices and technologies for odor control in swine production facilities and to summarize available data on odor reduction effectiveness of promising technologies, as well as provide information on key parameters and associated costs. Odors from swine facilities comprise hundreds of chemicals, including volatile organic compounds $(\mathrm{VOC})$, ammonia $\left(\mathrm{NH}_{3}\right)$, and hydrogen sulfide $\left(\mathrm{H}_{2} \mathrm{~S}\right)$. The medians of emission rates from swine houses in literature are $5 \mathrm{OU} / \mathrm{s} / \mathrm{pig}$ for odor, and 0.4, 2.8, and $0.1 \mathrm{~kg} / \mathrm{yr} / \mathrm{pig}$ for $\mathrm{VOC}, \mathrm{NH}_{3}$, and $\mathrm{H}_{2} \mathrm{~S}$ respectively. The medians of emission rates from swine manure storage facilities in literature are $5 \mathrm{OU} / \mathrm{s} / \mathrm{m}^{2}$ for odor, and 1.4, 2.1, and $0.2 \mathrm{~kg} / \mathrm{yr} / \mathrm{pig}$ for $\mathrm{VOC}, \mathrm{NH}_{3}$, and $\mathrm{H}_{2} \mathrm{~S}$, respectively. Facility maintenance and management practices to reduce impact of odor are reviewed in regard to regular cleaning of facilities, ventilation, floor design, drainage and manure removal systems, frequent manure removal, manure storage, and odor separation distances. Approaches to control odor and air pollution can be classified into three categories: ration/diet modification, manure treatment, capture/treatment of emitted gases and enhanced dispersion. Each of these mitigation approaches includes several specific technologies, which are summarized in tables with an evaluation of overall cost and brief comments on advantages or limitations of each technology. Diet modification strategies have been shown to reduce $\mathrm{NH}_{3}$ emissions effectively with low cost and should be considered as a best management practices, although their effectiveness in reducing odor is still uncertain. Permeable covers and biofilters seem to have great potential to be the most promising and cost effective technologies for manure storage facilities and swine houses respectively. However, both of the technologies need careful maintenance to perform effectively. Care must be taken to select technologies that are compatible with the management capabilities of the operation to prevent potential failure due to mismanagement.
\end{abstract}

Keywords. Ammonia, Biofilter, Cover, Diet, Manure, Emission, Hydrogen sulfide, Mitigation, Odor.

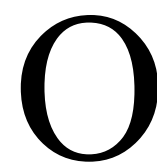
dor complaints have been identified as a major environmental challenge for the swine industry. Swine odors generate due to anaerobic decomposition of manure, feed materials, and wastewater. They are emitted from manure handling, storage and treatment facilities, as well as swine houses, especially when manure is held within the houses for more than 4 to 5 days (Riskowski, 2003). Although little is known about the connection between odor and human health, people generally have a natural aversion to manure odors. Swine odors may become a nuisance that can interfere with the neighbor's quality of life and property values of nearby communities. Increasingly stringent regulations of odor levels and air emissions can be limiting factors in the sustainable growth of the industry.

Submitted for review in November 2013 as manuscript number SE 10493; approved for publication by the Structures \& Environment Division of ASABE in February 2014.

The authors are Zifei Liu, ASABE Member, Assistant Professor, Department of Biological and Agricultural Engineering, Kansas State University, Manhattan, Kansas; and Wendy Powers, ASABE Member, Professor, Department of Animal Science, Michigan State University, East Lansing, Michigan; and Saqib Mukhtar, ASABE Member, Professor, Department of Biological \& Agricultural Engineering, Texas A\&M University, College Station, Texas. Corresponding author: Zifei Liu, Department of Biological \& Agricultural Engineering, Kansas State University, 154 Seaton Hall, Manhattan, KS 66506; phone: 785-532-3587; email: zifeiliu@ksu.edu.
Odors from swine facilities are the human olfactory response to a complex mixture of various odorous gases (odorants), which comprise hundreds of chemicals, including volatile organic compounds (VOC), ammonia $\left(\mathrm{NH}_{3}\right)$, and hydrogen sulfide $\left(\mathrm{H}_{2} \mathrm{~S}\right)$. A large number of odorants have been identified at very low concentrations (Zhang et al., 2002). Many compounds that have the lowest odor detection thresholds for humans contain sulfur (S) (O’Neill and Phillips, 1992). Zahn et al. (1997) indicated that volatile fatty acids (VFAs) with carbon numbers from 2 to 9 have the greatest potential to account for manure odor, while indole, phenol, $\mathrm{H}_{2} \mathrm{~S}$, methanethiol and other sulfur containing VOCs were also considered to be among the most important constituents of swine odor ( $\mathrm{Zhu}, 2000$; Riskowski, 2003; Feilberg et al., 2010). Odor intensity is a complex psychophysical variable in response to stimulation of mixture of odorants. Quantifying the contributions of each odorant to the overall odor intensity is a more difficult task than determination of concentrations of individual odorants (Zhang et al., 2002). Swine buildings have significant levels of airborne dust (80 90\% feed, 2 8\% manure, $2 \sim 12 \%$ from the pigs; Riskowski, 2003). Most gaseous odorants can be absorbed on and carried by airborne dust in swine buildings, and thus can travel long distances and be re-emitted from the dust (Bottcher, 2001). Ammonia can create strong odors near manure storage, but it is usually diluted quickly as it travels due to its high 
volatility (Chastain, 1999). Hydrogen sulfide is an extremely toxic and irritating gas at high levels, and has a generally objectionable rotten egg odor. Compared to $\mathrm{NH}_{3}$, $\mathrm{H}_{2} \mathrm{~S}$ concentrations are generally very low in swine houses, but when the manure is agitated, high quantities of $\mathrm{H}_{2} \mathrm{~S}$ can be released (Patni and Clarke, 1991).

Liu et al. (2013) found that swine hoop houses had significantly higher $\mathrm{NH}_{3}$ emission rates than other manurehandling systems, whereas deep pit houses had the highest $\mathrm{H}_{2} \mathrm{~S}$ emission rates, based on results of a meta-analysis on emission rates from swine houses for various production stages and manure handling systems in North America. Farrowing houses had the highest $\mathrm{H}_{2} \mathrm{~S}$ emission rates, followed by gestation houses, and finishing houses had the lowest $\mathrm{H}_{2} \mathrm{~S}$ emission rates, while the effects of production stages were not significant for $\mathrm{NH}_{3}$ emission rates from swine houses (Liu et al., 2013). The ranges of emission rates of odor, $\mathrm{VOC}, \mathrm{NH}_{3}, \mathrm{H}_{2} \mathrm{~S}$ from swine houses, as well as concentrations at the edge of swine facilities are presented in table 1.

Odor Units $(\mathrm{OU})$ can be used to describe odor concentration; one $\mathrm{OU} / \mathrm{m}^{3}$ is defined as the amount of odorant(s) in one cubic meter of air at the odor detection threshold. The numerical value of the odor concentration is equal to the dilution factor that is necessary to reach the odor threshold (Sweeten et al., 2001). The relationship between the odor intensity and the odorant or odor concentration is non-linear and varies for different odorants. Odor intensity usually increases as a power function of the odor or odorant concentration according to Stevens' law as follows: I = $\mathrm{kC}^{\mathrm{n}}$, where $\mathrm{I}$ is odor intensity, $\mathrm{C}$ is concentration of odorant or odor; and $\mathrm{k}$ and $\mathrm{n}$ are constants for a given odorant or odor (Stevens, 1961).

A previous review on odor nuisance from livestock building revealed that the literature had been concerned predominantly with single odorants while information on overall odor offensiveness was very scare (O'Neill and Phillips, 1992). Zhu et al. (2000) reviewed microbiology in swine manure odor control and admitted that research regarding how to control odor microbiologically was still in its infancy. Sweeten et al. (2001) pointed out that a paucity of data exists on odor emissions, and practical applications of many odor control technologies had not been widely demonstrated nor proven. Since then, various mitigation technologies to reduce air emissions from livestock operations have been evaluated. Literature reviews of measures and technologies for reducing $\mathrm{NH}_{3}$ have been carried out by Ndegwa et al. (2008) and Botermans et al. (2010). Aarnink and Verstegen (2007) reviewed nutritional strategies to reduce environmental load from swine production. VanderZaag et al. (2008) reviewed floating covers to reduce gas emissions from liquid manure stirage and found that information on many cover materials was limited to one or two studies. A critical review was provided by Haman et al. (2012), focusing on aerial pollutants in swine buildings, which described the complexity of the environment in swine buildings and emphasized the use of biological ways such as biofiltration for gases and odors treatment. Rahman and Borhan (2012) summarized typical odor mitigation technologies and focused on different stages of swine production, manure storage and handling, and land application; they found that applications of many mitigation technologies are limited due to their effectiveness to control odor, high costs, and the expertise required to operate the systems effectively. Scientific information on odor control in swine production facilities has not been readily accessible in an organized and consistent format. The objective of this article is to provide a systematic review on practices and technologies for odor control in swine production facilities and to summarize available data on odor reduction effectiveness of promising technologies, as well as information on key parameters and associated costs.

\section{Facility Maintenance and Management Practices TO REDUCE ODOR IMPACT}

Proper management and maintenance practices are essential to reduce impact of odor in swine production facilities. Many practices that help control odor also improve indoor air quality, thus may improve health and productivity for both workers and animals.

Regular cleaning of facilities. Manure and feed particles can attach to floors, walls, equipment, and pigs, and represent significant odor sources. Regular and thorough cleaning of all surfaces that may have attached organic material can reduce these odor sources. Designing the building and all facilities for easy cleaning is important. Smooth surfaces and easy access to all building areas for

Table 1. Emission rates from swine facilities and concentrations at the edge of swine facilities for odor, $\mathrm{VOC} \mathrm{NH}_{3}$, and $\mathrm{H}_{2} \mathrm{~S}$.

\begin{tabular}{|c|c|c|c|}
\hline & $\begin{array}{c}\text { Concentrations at the Edge } \\
\text { of Swine Facilities }\end{array}$ & $\begin{array}{c}\text { Emission Rates } \\
\text { from Swine Houses }\end{array}$ & $\begin{array}{c}\text { Emission Rates } \\
\text { from Manure Storage Facilities }\end{array}$ \\
\hline Odor & $120(40 \sim 960) \mathrm{OU} / \mathrm{m}^{3[\mathrm{a}]}$ & $5(0.4 \sim 24) \mathrm{OU} / \mathrm{s} / \mathrm{pig}^{[\mathrm{b}]}$ & $5(1 \sim 17) \mathrm{OU} / \mathrm{s} / \mathrm{m}^{2[\mathrm{c}]}$ \\
\hline VOC & $50(1 \sim 27700) \mu \mathrm{g} / \mathrm{m}^{3[\mathrm{~d}]}$ & $0.4(0 \sim 4.4) \mathrm{kg} / \mathrm{yr} / \mathrm{pig}^{[\mathrm{e}]}$ & $1.4(0 \sim 6.2) \mathrm{kg} / \mathrm{yr} / \mathrm{pig}^{[\mathrm{f}]}$ \\
\hline $\mathrm{NH}_{3}$ & $6(0.3 \sim 16) \mathrm{ppm}^{[\mathrm{g}]}$ & $2.8(0 \sim 32) \mathrm{kg} / \mathrm{yr} / \mathrm{pig}^{[\mathrm{h}]}$ & $2.1(0 \sim 23) \mathrm{kg} / \mathrm{yr} / \mathrm{pig}^{[\mathrm{h}]}$ \\
\hline $\mathrm{H}_{2} \mathrm{~S}$ & $20(2 \sim 115) \mathrm{ppb}^{[\mathrm{i}]}$ & $0.1(0 \sim 3.1) \mathrm{kg} / \mathrm{yr} / \mathrm{pig}^{[\mathrm{h}]}$ & $0.2(0 \sim 1.3) \mathrm{kg} / \mathrm{yr} / \mathrm{pig}^{[\mathrm{h}]}$ \\
\hline
\end{tabular}

Note: Values before the parentheses are medians; values within the parentheses are ranges reported in literature.

References:

[a] Lim et al., 2001; Lim et al., 2003; Godbout et al., 2009;. Rahman and Newman, 2012.

[b] Jacobson et al., 2003; Lim et al., 2003; Lim et al., 2004; Sun et al., 2010.

[c] Heber et al., 2000a,b; McGahan et al., 2001; Lim et al., 2003; Bicudo et al., 2004.

[d] Schiffman et al., 2001; Zahn et al., 2001b; Hermandez et al., 2012; Parker et al., 2012.

[e] Heber, 2010; Li et al., 2011.

[f] Zahn et al., 1997; Zahn et al., 2001b; Bicudo et al., 2004; Rumsey et al., 2012.

[g] Lim et al., 2000a; Childers et al., 2001; Zahn et al., 2001b; Walker et al., 2008.

[h] Liu et al, 2013.

[i] Zahn et al., 2001b; Lim et al., 2003; Hoff et al., 2009; Thorne et al., 2009. 
cleaning will be helpful (Riskowski. 2003). Quick disposal of mortalities, adhering to proper manure removal plans, and preventing water and feed waste are also important to reduce odor sources.

Ventilation. If buildings are kept clean, the next factor for odor control in swine facilities should be effective ventilation. A proper setting of the minimum ventilation rate is one of the first steps to maintaining a healthy environment for pigs and workers. The ventilation system should include properly sized fans, fresh air inlets, and controls. Minimum ventilation rates should be increased as the pigs gain weight (minimum $3.4 \mathrm{~m}^{3} / \mathrm{h}$ for nursery pigs and 17 to $100 \mathrm{~m}^{3} / \mathrm{h}$ for finishing pigs; Jacobson, 2011; Hamon et al., 2012).

Floor design. Floor design can have a large impact on dust and odor levels in swine houses. Solid concrete floors with scrapers or small flush gutters have more wet, manurecovered surfaces and tend to emit more odorous compounds than slatted floors (Chastain, 1999). Many swine facilities use either fully slatted or partially slatted floors to allow liquids to drain through to a manure pit or gutter. Hoop swine housing systems with bedding have been shown to have higher $\mathrm{NH}_{3}$ and $\mathrm{H}_{2} \mathrm{~S}$ emissions (Liu et al., 2013).

Drainage and manure removal systems. Good drainage of manure through a slatted floor can reduce odor sources by decreasing the area of waste influenced by slat design, width of openings, and material characteristics such as roughness and porosity (Braam and Swierstra, 1999). Replacing concrete slats with cast iron, metal, or plastic slats has been shown to reduce $\mathrm{NH}_{3}$ production (Pedersen and Ravn, 2008). Smooth floors have lower emissions. A partially slatted floor with reduced slurry pit area is known to have lower $\mathrm{NH}_{3}$ emission than a fully slatted floor (Philippe and Nicks, 2013). An alternative way to remove manure is by scraping. A typical flat-scraper system consists of a shallow slurry pit with a horizontal scraper under the slatted floor, but the surface area under the slat is a large emitting area (Predicala et al., 2007). Pit flushing has been shown to reduce $\mathrm{NH}_{3}$ emission by $45 \%$ compared to static pits (Lim et al., 2004).

Frequent manure removal. How often and well manure is removed from swine facilities greatly influences the amount of odor generated from these facilities. Frequency and cleaning ability of the flushing water both have a great impact (Misselbrook et al., 2006). Lim et al. (2004) reported that daily flushing reduced odor emissions by $41 \%$ and $34 \%$ as compared with the 7 and $14 \mathrm{~d}$ cycles, respectively. Using fresh water instead of recycled water can further reduce emissions.

Manure storage. Exposure of manure to the air will facilitate odor release (Zhao et al., 2007). Reducing the manure surface area and minimizing air circulation at the manure surface can be used to reduce emissions (Doorn et al., 2002; Timmerman et al., 2003). Altering the pit design to use sloped pit walls or manure gutters could reduce the manure surface area (Philippe and Nicks, 2013). The depth of the slurry channels also affects air movements over the slurry surface. Andersson (1995) observed that a $1.20-\mathrm{m}$ deep channel had $30 \%$ lower $\mathrm{NH}_{3}$ emissions than a $0.45-\mathrm{m}$ deep channel. Cooling the floor of the slurry channel also can reduce dissociation of $\mathrm{NH}_{3}$ and the $\mathrm{NH}_{3}$ transfer from the liquid to gas phase, thus reducing $\mathrm{NH}_{3}$ emissions (Starmans and van der Hoek, 2007). Cooling the floor of the slurry channel from $9^{\circ} \mathrm{C}$ to $5^{\circ} \mathrm{C}$ was observed to reduce $\mathrm{NH}_{3}$ emissions by $47 \%$ (Andersson, 1998), and Botermans et al. (2010) reported a 35\% reduction in $\mathrm{NH}_{3}$ emission with a temperature decrease of $2^{\circ} \mathrm{C}$. Loading rates for treatment lagoons should adhere to proper recommendations.

Odor separation distances. Odor decreases exponentially with distance. Properly siting new swine facilities and establishing a sufficient distance between these facilities and neighbors with consideration of prevailing winds can be effective ways to minimize odor nuisance, although this method may not be applicable for existing facilities. Setback distances adopted by Ontario, Iowa, and Illinois for livestock facilities depend roughly on animal type, land use, and total animal body weight and range from 0.23 to $2.4 \mathrm{~km}$ (Lim et al., 2000b), though Chastain (1999) claimed few swine facilities can generate odor that will travel more than $800 \mathrm{~m}$ ( 0.5 miles $)$. The ideal separation distance between a swine facility and the nearest neighbor to avoid odor nuisance is somewhat subjective. Odor dispersion is a complex process that depends on characteristics of the source, weather patterns, terrain, and the presence of other odor sources (Stowell et al., 2005). The factors that should be considered in the siting of new facilities include: direction of prevailing winds, distance to neighbors, topography, and presence of natural windbreaks. When planning a new facility in hilly areas, it is best to choose a site that is not up-slope from close neighbors to avoid downhill air drainage carrying odors to neighbors (Mukhtar and Zhang, 1995; Chastain, 1999). Several odor modeling tools have been developed to aid in the siting of new facilities and the expansion of current production sites, such as Community Assessment Model for Odor Dispersion (CAM; Hoff et al., 2008), Odor From Feedlots Setback Estimation Tool (OFFSET; Guo et al., 2005; Jacobson et al., 2005), and Odor Footprint Tool (OFT; Schulte et al., 2004). These tools can be used to determine minimum separation distances or predict receptor odor exposure from swine production sources. Wide variation in results have been reported when using different odor modeling tools especially when these tools were based on different methods (experience, combination of empirical and odor measurement, or odor dispersion calculation) (Guo et al., 2004). More efforts are needed to refine and validate these modeling tools, in order to use them with desired level of precision for land use decision-making.

\section{AVAILABle AND EMERging Mitigation TECHNOLOGIES FOR ODOR CONTROL}

During the last two decades, various mitigation technologies have been evaluated to reduce odor emissions from swine production facilities. Approaches to control odor and air pollution can be classified into three categories: ration/diet modification, manure treatment, capture/treatment of emitted gases and enhanced dispersion. 
Each of these mitigation approaches includes several specific technologies. Table 2 presents a summary of these technologies with an evaluation of overall cost and brief comments on advantages or limitations of each technology.

\section{DIET MODIFICATION}

Reducing dietary crude protein $(C P)$ content can result in reduced excretion of excess nutrients such as nitrogen (N) (Lenis, 1993), and thus can reduce $\mathrm{NH}_{3}$ (Leek et al., 2005; Powers et al., 2007) and odor (Hayes et al., 2004; Le et al., 2005) emissions from manure. Common diets usually supply more protein than is required to satisfy the requirement for the most limiting nutrients. To avoid overfeeding nutrients and enhance nutrient utilization in animals, dietary composition should be well balanced by matching dietary nutrients with pigs' requirements. A reduced $\mathrm{CP}$ diet can be used without effects on animal performance by supplementing with synthetic amino acids (AA) to provide the limiting nutrients in the diet (Lenis and Schutte, 1990; Botermans et al., 2010). Up to $40 \%$ reduction in swine $\mathrm{N}$ excretion has been reported by reducing dietary $\mathrm{CP}$ content and supplementing AA (Sutton et al., 1999; Portejoie et al., 2004; Powers et al., 2007; Le et al., 2009). Reduced $\mathrm{N}$ excretion due to reduced dietary CP content was found mainly through the reduction in urinary $\mathrm{N}$, and thus resulted in a lower ratio of urinary $\mathrm{N}$ to fecal $\mathrm{N}$
(Gatel and Grosjean, 1992; Canh et al., 1998). Reduced dietary CP content was also found to be associated with reduced manure pH (Portejoie et al., 2004; Hanni et al., 2007; Le et al., 2008). Reduction in urinary $\mathrm{N}$ and manure $\mathrm{pH}$ both favor reduction in $\mathrm{NH}_{3}$ emissions. Reducing dietary $\mathrm{CP}$ content and supplementing synthetic AA have been shown to be effective in reducing $\mathrm{NH}_{3}$ emissions from swine operations, but the effectiveness of these adjustments in reducing odor was not significant in most studies (table 3). Canh et al. (1998) estimated that for every percentage point reduction in dietary $\mathrm{CP}$ content (e.g., 14\% vs. $15 \%$ dietary $\mathrm{CP}$ concentration), a $10 \%$ reduction in total ammonical nitrogen (TAN) excretion and a $10 \%$ to $12.5 \%$ reduction in $\mathrm{NH}_{3}$ emissions from manure can be expected. Otto et al. (2003) concluded that the reduction in $\mathrm{NH}_{3}$ emission was linear with a decrease in dietary protein only over a certain range of dietary $\mathrm{CP}$ intake in which $\mathrm{N}$ utilization would not have been maximized. The median of reduction in $\mathrm{NH}_{3}$ emissions for every percentage point reduction in dietary $\mathrm{CP}$ content in the literature was $9.4 \%$ (value ranged from 0 to $30 \%$, table 3 ). As a pig's nutrient requirement changes with age, multi-phase feeding that match dietary nutrients with the requirements of the pigs at different ages can be used to avoid wasting nutrients and to minimize $\mathrm{NH}_{3}$ emissions. Van Kempen and van Heugten (2002) reported that a two-phase feeding program can

Table 2. Summary of technologies for odor control in swine production facilities.

\begin{tabular}{|c|c|c|c|c|c|c|}
\hline & \multirow[b]{2}{*}{ Technology } & \multirow[b]{2}{*}{ Effectiveness } & \multicolumn{3}{|c|}{ Cost } & \multirow[b]{2}{*}{ Comments } \\
\hline & & & $\begin{array}{l}\text { Installation } \\
\text { (\$ per pig } \\
\text { space) }\end{array}$ & $\begin{array}{l}\text { Operation } \\
\text { (\$ per pig } \\
\text { produced) }\end{array}$ & Overall & \\
\hline $\begin{array}{l}\text { Ration/diet } \\
\text { modification }\end{array}$ & $\begin{array}{l}\text { Low CP content } \\
\text { diets and/or feed } \\
\text { additives }\end{array}$ & Moderate & - & $<\$ 0.5^{[\mathrm{a}]}$ & Low & $\begin{array}{l}\text { Use of synthetic amino acids to reduce diet CP } \\
\text { and cost is well established, and is a common } \\
\text { industry practice; should be considered as a BMP. }\end{array}$ \\
\hline \multirow{5}{*}{$\begin{array}{l}\text { Manure } \\
\text { handling and } \\
\text { treatment }\end{array}$} & $\begin{array}{l}\text { Solid-liquid } \\
\text { separation }\end{array}$ & Moderate & $\$ 22 \sim \$ 27^{[\mathrm{b}]}$ & $\$ 2 \sim \$ 3^{[b]}$ & $\begin{array}{l}\text { Moderate to } \\
\text { high }\end{array}$ & $\begin{array}{l}\text { More research is needed to develop practical } \\
\text { techniques for immediate separation of solids } \\
\text { from freshly excreted manure. }\end{array}$ \\
\hline & Storage additives & Uncertain & $\$ 1.2^{[\mathrm{c}]}$ & $\$ 0.5^{[\mathrm{c}]}$ & Moderate & $\begin{array}{l}\text { Only works for a short period or specific } \\
\text { odorants; need further research to improve } \\
\text { reliability. }\end{array}$ \\
\hline & $\begin{array}{c}\text { Impermeable } \\
\text { storage covers }\end{array}$ & High & $\$ 6 \sim \$ 32^{[\mathrm{d}]}$ & - & Moderate & $\begin{array}{l}\text { A venting system and a support structure may be } \\
\text { needed. }\end{array}$ \\
\hline & $\begin{array}{l}\text { Permeable storage } \\
\text { covers }\end{array}$ & Moderate & $\$ 0.6 \sim \$ 5^{[\mathrm{d}]}$ & - & $\begin{array}{l}\text { Low to } \\
\text { moderate }\end{array}$ & $\begin{array}{l}\text { Effectiveness highly dependent on how the cover } \\
\text { is managed. }\end{array}$ \\
\hline & $\begin{array}{c}\text { Anaerobic } \\
\text { digestion }\end{array}$ & High & $\$ 22 \sim \$ 150^{[\mathrm{e}],[\mathrm{f}]}$ & - & High $^{[\mathrm{g}]}$ & $\begin{array}{l}\text { Not economically feasible for small operations; } \\
\text { has problem of } \mathrm{NH}_{3} \text { inhibition; has more } \\
\text { potentials through co-digestion. }\end{array}$ \\
\hline \multirow{4}{*}{ Air treatment } & Oil spraying & $\begin{array}{c}\text { Low to } \\
\text { moderate }\end{array}$ & $\sim \$ 6^{[\mathrm{e}]}$ & $\sim \$ 0.7^{[\mathrm{e}]}$ & Moderate & $\begin{array}{l}\text { Create slick flooring for pigs and people; health } \\
\text { concern on oil misting. }\end{array}$ \\
\hline & Biofilters & High & $\$ 4 \sim \$ 11^{[\mathrm{e}]}$ & $\$ 0.05 \sim \$ 0.1^{[\mathrm{e}]}$ & $\begin{array}{l}\text { Low to } \\
\text { moderate }\end{array}$ & $\begin{array}{l}\text { A promising technology; need careful } \\
\text { maintenance. }\end{array}$ \\
\hline & Wet scrubbers & Moderate & $\sim \$ 40^{[\mathrm{e}]}$ & $\sim \$ 2^{[\mathrm{e}]}$ & $\begin{array}{l}\text { Moderate to } \\
\text { high }\end{array}$ & $\begin{array}{l}\text { Need treatment for wastewater; effectiveness on } \\
\text { odor depends on solubility of odorants. }\end{array}$ \\
\hline & $\begin{array}{c}\text { Vegetative } \\
\text { environmental } \\
\text { buffers } \\
\end{array}$ & $\begin{array}{l}\text { Low to } \\
\text { moderate }\end{array}$ & $\sim \$ 1^{[\mathrm{h}]}$ & $\$ 0.05 \sim \$ 0.20^{[\mathrm{h}]}$ & Low & $\begin{array}{l}\text { Decreases direct visual viewing of facilities; may } \\
\text { decrease natural ventilation in summer; requires } \\
\text { planning and time. }\end{array}$ \\
\hline \multicolumn{7}{|c|}{$\begin{array}{l}\text { Note: } \mathrm{CP}=\text { crude protein; BMP }=\text { best management practices. } \\
\text { [a] Depends on price of synthetic amino acids; the cost of low CP diets sometimes can be lower than regular diets. } \\
\text { [b] Based on a gravity screen system or a gravity belt thickener system, Walker and Wade, } 2009 . \\
\text { [c] Based on addition of a commercial manure additive (Alliance }(\mathrm{R}) \text {, Heber et al., 2000a. } \\
\text { [d] Calculation was based on assumption of } 2.1 \mathrm{~m}^{2} \text { lagoon area per pig space; adapted from Stenglein et al., } 2011 . \\
\text { [e] Data were adapted from resources of eXtension. Available online at http://www.extension.org/pages/23980/technologies-for-mitigating-air- } \\
\text { emissions-in-swine-production } \\
\text { [f] Calculation was based on installation of an anaerobic digestion system for a capacity of } 4,000 \text { pigs. } \\
\text { [g] Cost effectiveness depends on the value of energy recovery from biogas. } \\
\text { [h] Data were adapted from Iowa demonstration cooperators and Tyndall, } 2008 .\end{array}$} \\
\hline
\end{tabular}


Table 3. Effectiveness of reducing diet $\mathrm{CP}$ content for reducing odor and $\mathrm{NH}_{3}$ emissions.

\begin{tabular}{|c|c|c|c|c|c|}
\hline \multirow[b]{2}{*}{ References } & \multicolumn{2}{|c|}{ Diet CP Content Reduced } & \multicolumn{2}{|c|}{ Reduction in Emissions } & \multirow{2}{*}{$\begin{array}{c}\mathrm{NH}_{3} \text { Reduction per } \\
\text { Percentage Point Reduction } \\
\text { in Dietary CP (\%) }\end{array}$} \\
\hline & From $(\%)$ & To $(\%)$ & Odor & $\mathrm{NH}_{3}(\%)$ & \\
\hline Hernandez et al., 2011 & 16 & 14 & - & $0 \sim 13$ & $0 \sim 6.5$ \\
\hline Le et al., 2009 & 15 & 12 & Not significant & 29 & 9.7 \\
\hline Cho et al., 2008 & 19.5 & 16.0 & - & 26 & 7.4 \\
\hline \multirow{2}{*}{ Powers et al., 2007} & 22.1 & 18.8 & - & 22 & 6.7 \\
\hline & 18.8 & 17.2 & - & 33 & 20.6 \\
\hline \multirow{2}{*}{ Le et al., 2007b, 2008} & 18 & 15 & $59 \%$ & 47 & 15.7 \\
\hline & 15 & 12 & $44 \%$ & 11 & 3.7 \\
\hline \multirow{2}{*}{ Panetta et al., 2006} & 17.4 & 17.0 & - & 12 & 30 \\
\hline & 17.0 & 14.5 & - & 51 & 20.4 \\
\hline Philippe et al., 2006 & 17.8 & 14.7 & - & 26 & 8.4 \\
\hline Clark et al., 2005 & 16.8 & 13.9 & Not significant & - & - \\
\hline Velthof et al., 2005 & 18.0 & 14.2 & - & 52 & 13.7 \\
\hline \multirow{3}{*}{ Hayes et al., 2004} & 22 & 19 & Increased by $11 \%$ & 29 & 9.7 \\
\hline & 19 & 16 & $33 \%$ & 34 & 11.3 \\
\hline & 16 & 13 & $8 \%$ & 20 & 6.7 \\
\hline \multirow{2}{*}{ Portejoie et al., 2004} & 20 & 16 & - & 20 & 5 \\
\hline & 16 & 12 & - & 18 & 4.5 \\
\hline Otto et al., 2003 & 15 & 12 & Not significant & 50 & 16.7 \\
\hline Kendall et al., 1998, 1999 & 16.7 & 12.2 & Not significant & 41 & 9.1 \\
\hline Kay and Lee, 1997 & 20 & 13 & - & $47 \sim 59$ & $6.7 \sim 8.4$ \\
\hline Obrock et al. 1997 & 13 & 9 & Not significant & 29 & 7.2 \\
\hline \multirow{2}{*}{ Turner et al., 1996} & 16 & 12 & - & 79 & 19.8 \\
\hline & 14 & 10 & - & 58 & 14.5 \\
\hline
\end{tabular}

reduce $\mathrm{N}$ excretion by $13 \%$, and a three-phase feeding program can reduce $\mathrm{N}$ excretion by $17.5 \%$. Van der PeetSchwering and Voermans (1996) observed that multiphase feeding reduced urinary $\mathrm{N}$ excretion by $14.7 \%$ and $\mathrm{NH}_{3}$ emission by $16.8 \%$.

Feed additives can be used to increase the digestibility and absorption of nutrients (Botermans et al., 2010) and to influence $\mathrm{N}$ excretion and $\mathrm{pH}$ of manure (Bakker and Smits, 2002). Addition of fermentable carbohydrates can shift $\mathrm{N}$ excretion from urine (quickly degradable urea) to feces (slowly degradable microbial protein) and lower feces pH (Sutton et al., 1999; Le et al., 2008; Groenestein et al., 2011). Addition of acidifying salts can lower urinary $\mathrm{pH}$ (Kim et al., 2004) and could reduce $\mathrm{NH}_{3}$ emission by up to $40 \%$ (Botermans et al., 2010). Benzoic acid has been evaluated as an emission-reducing additive for swine feed (Aarnink et al., 2008). Addition of xylanase to wheat-based diets may improve nutrient digestibility and pig growth (Kim et al., 2005), and it has been shown to induce 54\% reduction in odor emissions in lab scale studies (O'Shea et al., 2010; Alpine et al., 2012). By combining various dietary strategies, up to $70 \%$ reduction in $\mathrm{NH}_{3}$ emission could be achieved (Aarnink and Verstegen, 2007). To reduce odor emissions, dietary sulfur-containing AA should be minimized to meet the recommended requirements (Le et al., 2007a). In recent years, co-products of ethanol such as dried distillers grain with solubles (DDGS) have been used to replace a portion of the grain in swine feed. Increased DDGS content in the diets can result in increased production of VFAs and increased odor, $\mathrm{NH}_{3}$, and $\mathrm{H}_{2} \mathrm{~S}$ emissions (Powers and Angel, 2008; Pepple et al., 2010; Li et al., 2011). Yoon et al. (2010) and Gralapp et al. (2002) showed adding $5 \%$ to $15 \%$ DDGS had no negative effects on odor emissions. Limiting DDGS content in late finishing phase diets to $20 \%$ or less is recommended to avoid undesirable effects on carcass quality.

\section{Manure Handing ANd Treatment}

Solid-liquid separation of manure is a physical means to reduce odor by mechanical or gravitational separation of solids from liquid manure, and process generated wastewater. Separated liquid will have lower biodegradable organic matter for anaerobic degradation, and separated solids will have much smaller volumes and air-manure contact surface, thus reducing odor emissions. The $\mathrm{N}$ in urine is mainly in the form of urea, and it is converted into volatile $\mathrm{NH}_{3}$ after it is in contact with feces containing urease (Mobley and Hausinger, 1989). If urine to feces contact is reduced, $\mathrm{NH}_{3}$ formation will be reduced (Szögi and Vanotti, 2007; Powers, 2009). Effectiveness of solidliquid separation on odor reduction is highly variable, depending on the time between excretion and separation, and the separation efficiency (Kroodsma, 1985). Solidliquid separation should occur within 10 days of manure excretion to prevent decomposition of fine manure particles (Zhu et al., 2000) and ideally should occur immediately after manure is excreted to minimize odor emissions. Separation is challenging once the feces and urine have been mixed (Ndegwa, 2003). Common separation units include gravity settling/sedimentation and mechanical screening, which require additional space and maintenance. More research is needed to incorporate the concept of solid-liquid separation into planning and design of the manure handling systems.

Storage additives have been proposed to be added to the manure storage pit or sprayed on the manure to control odors. Various manure storage additives have been studied in lab and field settings (table 4). Common additives include biological additives (enzymatic or bacterial products); chemical additives (acid, disinfectants, or oxidizing agents); and adsorbent and masking agents (Chastain, 1999). Use of adsorbent and masking agents has 
had limited success in reducing odors from swine facilities. Biological additives are usually odorant-specific (McCrory and Hobbs, 2001). Many additives were effective in reducing certain odorants but their impact on overall odor emissions was questionable. Also, research showed that additives that were effective in the lab may not be effective in field settings (Banhazi et al., 2009). In some cases the observed reduction in odor was found to be reversible (Nykanen et al., 2010). Further research is needed to improve reliability of these additives. Chemical additives are often effective only for a short period of time, and thus require frequent applications and become costly (Ritter, 1989; McCrory and Hobbs, 2001). Slurry acidification can effectively reduce $\mathrm{NH}_{3}$ emission, and improve $\mathrm{S}$ and $\mathrm{N}$ fertilizer value of treated slurry, and it is approved Best Available Technology in Denmark (Kai et al., 2008). Nevertheless, inorganic $S$ in the acidified slurry may facilitate odor from volatile S-containing compounds
(Eriksen et al., 2008), and slurry acidification may not be effective in reducing overall odor emissions.

Storage covers are being used to reduce odors from liquid manure storage structures and lagoons. Covers are usually classified as permeable [e.g., straw, Geotextile ${ }^{\mathbb{R}}$ (a synthetic permeable cover), or a combination of both] which allow the slow release of gases from storage, or impermeable (plastic, concrete, or wood), which do not allow manure emissions to be released to the atmosphere (Stenglein et al., 2011; Nicolai et al. 2002). Both permeable and impermeable floating covers decrease odor emissions by decreasing the solar radiation and direct wind velocity that transport odor constituents (Rahman and Borhan, 2012). Permeable covers have been shown to have various effectiveness in reducing odor, $\mathrm{NH}_{3}$, and $\mathrm{H}_{2} \mathrm{~S}$ emissions from swine manure storage facilities (table 5). Some permeable covers are thought to act as biofilters on top of stored liquid manure (Lupis et al., 2012). A straw thickness of $30 \mathrm{~cm}$ is needed to keep straw afloat, keep the upper portion

Table 4. Effectiveness of manure storage additives for reducing odor emissions.

\begin{tabular}{|c|c|c|c|}
\hline References & Description of the Additives & Reduction in Emissions & Comments \\
\hline $\begin{array}{l}\text { Dai and Blanes- } \\
\text { Vidal., } 2013\end{array}$ & Sulphuric acid & $\begin{array}{l}\text { Reduced } \mathrm{NH}_{3} \text { emission by } 50 \% \sim 77 \% \text {, } \\
\text { no effects on } \mathrm{H}_{2} \mathrm{~S} \text { emission }\end{array}$ & Reduced $\mathrm{pH}$ to $5.5 \sim 6.0$, lab study \\
\hline $\begin{array}{l}\text { Shah and Kolar, } \\
2012\end{array}$ & $\begin{array}{l}\text { ManureMax } ®(12.02 \% \text { humic acids, } \\
1.44 \% \text { potassium, } 0.61 \% \text { sodium, } 0.13 \% \\
\text { phosphorus, } 0.11 \% \text { nitrogen, } 0.004 \% \text { iron, } \\
\text { and } 85.35 \% \text { inert })\end{array}$ & $\begin{array}{l}\text { Reduced } 2 \text {-butanone, and tetrahydrofuran } \\
\text { concentrations by } 44 \% \text { and } 57 \% \text {, respectively }\end{array}$ & $\begin{array}{l}\text { Were effective for four weeks, } \\
\text { tested in lagoon }\end{array}$ \\
\hline $\begin{array}{l}\text { Parker et al., } \\
2012\end{array}$ & Soybean peroxidase plus peroxide & $\begin{array}{l}\text { Reduced emissions of the primary odorant } \\
\text { 4-methylphenol and corresponding odor activity } \\
\text { value by } 62 \sim 98 \% \text { and } 68 \sim 94 \% \text {, respectively }\end{array}$ & $\begin{array}{l}\text { Resulted in a } 10 \text {-fold increase in } \\
\text { VFA emissions, tested in wind } \\
\text { tunnel }\end{array}$ \\
\hline $\begin{array}{l}\text { Rahman et al., } \\
2011\end{array}$ & Digest3+3C microbial additive & $\begin{array}{l}\text { No significant differences in odor, } \mathrm{NH}_{3} \text {, and } \mathrm{H}_{2} \mathrm{~S} \\
\text { emissions }\end{array}$ & $\begin{array}{l}\text { Tested in a commercial swine } \\
\text { operation }\end{array}$ \\
\hline $\begin{array}{l}\text { Nykanen et al., } \\
2010\end{array}$ & Carbohydrate and bacterial amendments & Reduced volatile sulfur compounds & $\begin{array}{l}\text { The observed reduction in odor } \\
\text { was found to be reversible, } \\
\text { included both lab and full scale } \\
\text { studies }\end{array}$ \\
\hline $\begin{array}{l}\text { Banhazi et al., } \\
2009\end{array}$ & $\begin{array}{l}\text { WonderTreat }{ }^{\mathrm{TM}} \text { (a yeast-based product } \\
\text { from CK Life Sciences International, Inc., } \\
\text { Hong-Kong) }\end{array}$ & $\begin{array}{l}\text { Reduced odor by } 30 \% \text { in lab trials, but showed no } \\
\text { significant effect in a lagoon test }\end{array}$ & $\begin{array}{l}\text { Not consistent in lab and field } \\
\text { studies }\end{array}$ \\
\hline $\begin{array}{l}\text { Ottosen et al., } \\
2009\end{array}$ & Sulphuric acid & Eliminated $\mathrm{NH}_{3}$ emission & $\begin{array}{l}\text { Reduced pH from } 7.5 \text { to } 5.5 \text {, } \\
\text { increased VFA concentrations by } \\
\text { two orders, tested in a slurry pit }\end{array}$ \\
\hline Ye et al., 2009 & $\begin{array}{l}\text { Horseradish peroxidase and } \\
\text { Peroxides }\end{array}$ & $\begin{array}{l}100 \% \text { reduction in p-cresol, } 54 \sim 84 \% \text { reduction in } \\
\text { odor intensity, 32 54\% reduction in indolic } \\
\text { compounds and } 28 \sim 41 \% \text { reduction of VFAs }\end{array}$ & $\begin{array}{l}\text { The effect of deodorization can } \\
\text { last for at least } 48 \mathrm{~h} \text {, lab study }\end{array}$ \\
\hline Kai et al., 2008 & Sulphuric acid & $\begin{array}{l}\text { Reduced } \mathrm{NH}_{3} \text { emissions by } 70 \% \text {, but no effects on } \\
\text { odor emission }\end{array}$ & $\begin{array}{l}\text { Increase mineral fertilizer } \\
\text { equivalent, a whole farm study }\end{array}$ \\
\hline $\begin{array}{l}\text { Predicala et al., } \\
2008\end{array}$ & Na-nitrite and Na-molybdate & $\begin{array}{l}\text { Reduced } \mathrm{H}_{2} \mathrm{~S} \text { significantly, but no effects on } \mathrm{NH}_{3} \\
\text { and odor intensity }\end{array}$ & $\begin{array}{l}\text { Included lab and semi-pilot scale } \\
\text { studies }\end{array}$ \\
\hline $\begin{array}{l}\text { Govere et al., } \\
2007\end{array}$ & $\begin{array}{l}\text { Minced horseradish roots and peroxides } \\
\text { (1:10 roots to swine slurry ratio) }\end{array}$ & Complete removal of phenolic odorants & $\begin{array}{l}\text { The plant material can be reused, } \\
\text { pilot scale }(20 \sim 120 \mathrm{~L}) \text { study }\end{array}$ \\
\hline Lee et al., 2007 & Aqueous foam & $\begin{array}{l}\text { Reduced } \mathrm{NH}_{3} \text { and } \mathrm{H}_{2} \mathrm{~S} \text { emissions by } 88 \% \text { and } \\
70 \% \text {, respectively }\end{array}$ & Lab study \\
\hline $\begin{array}{l}\text { Varel and Wells, } \\
2007\end{array}$ & Thymol and urease inhibitor & Thymol reduced VFA by $64 \% \sim 100 \%$ & $\begin{array}{l}\text { Urease inhibitor produced a } \\
\text { temporary }(6 \sim 10 \mathrm{~d}) \text { response in } \\
\text { conserving urea, tested in slurry } \\
\text { pits }\end{array}$ \\
\hline $\begin{array}{l}\text { Huang et al., } \\
2006\end{array}$ & L. plantarum and soluble carbohydrates & Reduced $\mathrm{NH}_{3}$ emissions by $34 \sim 92 \%$ & $\begin{array}{l}\text { Increase } \mathrm{H}_{2} \mathrm{~S} \text { emissions } \\
\text { significantly, lab study }\end{array}$ \\
\hline $\begin{array}{l}\text { Schneegurt et al., } \\
2005\end{array}$ & $\begin{array}{l}\text { Bio-Kat (a formulation contains marine } \\
\text { algal extracts, plant-derived surfactants, } \\
\text { and anti-foaming agents, from NRP Group, } \\
\text { Inc.) }\end{array}$ & $\begin{array}{l}\text { Reduced } \mathrm{NH}_{3} \text { emission by } 75 \% \text { after } 3 \text {-wk } \\
\text { treatment }\end{array}$ & $\begin{array}{l}\text { Also reduced total and volatile } \\
\text { solids, tested in lagoon }\end{array}$ \\
\hline $\begin{array}{l}\text { Smith et al., } \\
2004\end{array}$ & Aluminum chloride solution & $\begin{array}{l}\text { Reduced } \mathrm{NH}_{3} \text { emission by } 52 \% \text { for the } 6 \text {-wk } \\
\text { period }\end{array}$ & $\begin{array}{l}\text { Reduced } \mathrm{pH} \text { from } 7.5 \text { to } 6.7 \text {, } \\
\text { chamber study }\end{array}$ \\
\hline $\begin{array}{l}\text { Heber et al., } \\
2000 \mathrm{a}\end{array}$ & $\begin{array}{l}\text { Alliance }{ }^{\circledR} \text { (Monsanto EnviroChem, St. } \\
\text { Louis, Mo.) }\end{array}$ & Reduced $\mathrm{NH}_{3}$ emissions by $24 \%$ & $\begin{array}{l}\text { Tested in commercial swine } \\
\text { building }\end{array}$ \\
\hline Zhu et al., 1997 & $\begin{array}{l}\text { Five commercial pit additives } \\
\text { (MPC, Bio-Safe, Shac, X-Stink, CPPD) }\end{array}$ & All treatments reduced odor levels by $58 \% \sim 87 \%$ & Lab study \\
\hline
\end{tabular}


dry, and allow the straw to absorb gases and act as a biofilter, but Geotextile ${ }^{\circledR}$ thickness has no impact on odor and gas emissions (Clanton et al., 2001). As can be seen in table 3, a straw cover can be expected to reduce odor by more than $60 \%$ when its thickness is larger than $15 \mathrm{~cm}$ (Hornig et al., 1999; Clanton et al., 2001; Guarino et al., 2006). This is comparable with the conclusion of VanderZaag et al. (2008), who indicated a straw cover thickness of $>20 \mathrm{~cm}$ is needed. Guarino et al. (2006) and Blanes-Vidal et al. (2009) reported no significant effect on odor reduction when straw cover thickness is $7 \sim 10 \mathrm{~cm}$. However, it is still possible for a well maintained straw cover to reduce more than $60 \%$ odor in spite of a thickness of $10 \mathrm{~cm}$ or less (Hornig et al., 1999; Hudson et al., 2006a, 2008). Odor reductions by Geotextile ${ }^{\mathbb{R}}$ cover were in the range from 39 to $78 \%$ (Clanton et al., 1999, 2001; Bicudo et al., 2004). Floating permeable covers are simple and inexpensive ( $\$ 0.3$ to $\$ 1 / \mathrm{m}^{2}$ for straw, $\$ 1$ to $\$ 2.4 / \mathrm{m}^{2}$ for Geotextile ${ }^{\circledR}$ ) but they degrade in a relatively short time period ( 2 to 6 months for straw due to saturation and sinking; 3 to 5 years for Geotextile ${ }^{\circledR}$ ) (Bicudo et al., 2004; Nicolai et al., 2002). The performance of straw covers depends on the straw's ability to float on the surface. Buoyancy or support is essential if consistent performance is required (Hudson et al., 2008). Straw covers and other similar materials may not be economically viable to cover lagoons with large surface areas, since these covers will eventually sink and cause additional sludge production in the lagoon bottom. Impermeable covers have higher capital costs ( $\$ 3$ to $\$ 15 / \mathrm{m}^{2}$ ) and have life expectancy as long as 10 years (Zhang and Gaakeer, 1998; Nicolai et al., 2002; Stenglein et al., 2011). Impermeable covers usually require a venting system to avoid pressure buildup under the cover due to production of manure gases (Bicudo et al., 2003) and require a system for removing rain and snowmelt. Covering lagoons may also reduce evaporation, thus requiring either more frequent irrigation pumping or greater lagoon volume (Lupis et al., 2012).

Anaerobic digestion is a widely applied technology for stabilization of organic waste and production of biogas and is one of the most effective end-of-pipe methods of reducing odor and air pollutants from swine manure (Botermans et al., 2010). Anaerobic digestion has been shown to reduce VFAs by $79 \%$ to $97 \%$, and thus reduces odor emissions (Hansen et al. 2006). Chantigny et al. (2009) claimed that $\mathrm{NH}_{3}$ volatilization was $22 \%$ less for anaerobically digested manure following surface application in comparison to untreated manure. However, there are uncertainties in how the anaerobic digestion process affects $\mathrm{NH}_{3}$ emissions since it depends on the $\mathrm{pH}$ in the digester (Strik et al, 2006). Due to high cost, anaerobic digestion generally is not economically feasible for small operations (Rahman and Borhan, 2012). Cost effectiveness of anaerobic digestion is dependent on the value of energy recovery from biogas; such as through a contract with an electrical utility company. The high content of $\mathrm{NH}_{3}$ has been a limitation for digestion of swine manure (Hansen et al., 1998). Co-digestion of manure with carbon-based substrates recently has renewed interest in enhancing the biogas production efficiency and economic viability of anaerobic digestion (Astals et al., 2012).

\section{Air Treatment}

Biofiltration is an air-cleaning technology for the exhaust air from swine housing and sub-surface pits for manure storage. The contaminated air passes through a filter media where microorganisms break down gaseous contaminants. Biofilters are made of moist and porous material with a large surface area in which odorants can be adsorbed and microorganisms can grow (Rahman and Borhan, 2012). If properly designed and maintained, biofilters can reduce up to $90 \%$ of emissions of odor, $\mathrm{NH}_{3}$, and $\mathrm{H}_{2} \mathrm{~S}$ from ventilation fan exhausts (table 6). Biofilter media moisture content and empty bed residence time (EBRT) have been identified as the most important design and operation parameters (Schmidt et al., 2004; Chen and Hoff, 2012). A 5-s EBRT has been recommended for adequate odor and $\mathrm{H}_{2} \mathrm{~S}$ reduction from swine facilities

Table 5. Effectiveness of permeable covers for reducing odor, $\mathrm{H}_{2} \mathrm{~S}$, and $\mathrm{NH}_{3}$ emissions.

\begin{tabular}{|c|c|c|c|c|}
\hline \multirow[b]{2}{*}{ References } & \multirow[b]{2}{*}{ Description of Covers } & \multicolumn{3}{|c|}{ Reduction in Emissions } \\
\hline & & Odor $(\%)$ & $\mathrm{H}_{2} \mathrm{~S}(\%)$ & $\mathrm{NH}_{3}(\%)$ \\
\hline Blanes-Vidal et al., 2009 & Straw, $10 \mathrm{~cm}$ thick & Not significant & Not significant & $47 \sim 99$ \\
\hline \multirow{3}{*}{ Hudson et al., 2008} & Polypropylene-shade cloth, $4.4 \mathrm{~mm}$ thick & 76 & - & - \\
\hline & Shade cloth only & 69 & - & - \\
\hline & Supported straw, $10 \mathrm{~cm}$ thick & 66 & - & - \\
\hline \multirow{2}{*}{ Guarino et al., 2006} & Wheat straw, $7 \mathrm{~cm}$ thick & Not significant & - & 34 \\
\hline & Wheat straw, $15 \mathrm{~cm}$ thick & 61 & - & 86 \\
\hline Hudson et al., 2006a & Supported straw, $10 \mathrm{~cm}$ thick & $71 \sim 84$ & - & - \\
\hline Hudson et al., 2006b & Supported straw, $10 \sim 12.5 \mathrm{~cm}$ thick & $87 \sim 90$ & - & - \\
\hline Cicek et al., 2004 & Straw & 38 & - & - \\
\hline Bicudo et al., 2004 & Geotextile $^{\circledR}$, non-woven, $6.35 \mathrm{~mm}$ thick & 50 & 72 & $30 \sim 45$ \\
\hline Zahn et al., 2001a & $0.3 \mathrm{~mm}$ geotextile and $3.2 \mathrm{~mm}$ closed -cell polypropylene foam. & - & $23 \sim 58$ & $17 \sim 54$ \\
\hline Miner et al., 2001 & $\begin{array}{l}5 \mathrm{~cm} \text { foam board made of post-industrial recycled, closed-cell } \\
\text { polyethylene foam, and a proprietary biocover. }\end{array}$ & - & - & $76 \sim 96$ \\
\hline \multirow{4}{*}{ Clanton et al., 2001} & Geotextile $^{\circledR}, 2.4 \mathrm{~mm}$ thick & 39 & 31 & 0 \\
\hline & Straw, $30 \mathrm{~cm}$ thick & 76 & 85 & 86 \\
\hline & Straw, $20 \mathrm{~cm}$ thick & 69 & 82 & 72 \\
\hline & Straw, $10 \mathrm{~cm}$ thick & 47 & 59 & 37 \\
\hline Clanton et al., 1999 & Geotextile $^{(R)}, 0.3 \mathrm{~mm}$ thick & $60 \sim 78$ & - & - \\
\hline Hornig et al., 1999 & Straw, 5 and $15 \mathrm{~cm}$ thick & $83 \sim 91$ & - & $80 \sim 91$ \\
\hline Xue et al., 1999 & Straw, $10 \mathrm{~cm}$ thick & - & Up to 95 & Up to 95 \\
\hline Karlsson, 1996 & A floating plastic foil and a peat layer & - & - & 85 \\
\hline
\end{tabular}


(Nicolai et al., 2004a). Reported effectiveness of biofilters in reducing odor, $\mathrm{NH}_{3}$ and $\mathrm{H}_{2} \mathrm{~S}$ all increase with increasing EBRT, while reductions of $\mathrm{NH}_{3}$ and $\mathrm{H}_{2} \mathrm{~S}$ seem to be more sensitive to EBRT as compared to reduction of odor. A biofilter can be expected to reduce both $\mathrm{NH}_{3}$ and $\mathrm{H}_{2} \mathrm{~S}$ by more than $80 \%$ when EBRT is $\geq 10$ s (Sun et al., 2000; Chang et al., 2004). When EBRT is $\sim 5 \mathrm{~s}$, reductions by biofilters were in the range of $25 \%$ to $93 \%$ for $\mathrm{NH}_{3}, 47 \%$ to $83 \%$ for $\mathrm{H}_{2} \mathrm{~S}$, and $51 \%$ to $95 \%$ for odor (table 6). Desirable media properties include high moisture-holding capacity and high pore space to maximize EBRT and minimize pressure drop (Swanson and Loehr, 1997). Examples of biofilter media include peat, soil, compost, wood chips, sawdust, straw, or a combination of different materials (Nicolai and Janni, 2000). Performance of biofilters depends on microbial activity, which is very complicated and is influenced by temperature, nutrient availability, moisture, pH, and airflow rate (Zhang et al., 2002). Design and operational parameters such as selection of packing material, maintaining optimum moisture content, weed control, and assessing pressure drop are critical to efficient operation of the biofilters (Chen and Hoff, 2012; Rahman and Borhan, 2012). In general, recommended operating conditions for biofilters are: moisture of $40 \%$ to $65 \%$, temperature of $25^{\circ} \mathrm{C}$ to $50^{\circ} \mathrm{C}$, and media porosity of $40 \%$ to 60\% (Nicolai and Janni, 2000; Nicolai and Lefers, 2006; Rahman and Borhan, 2012). Maintaining operating conditions with a supply of moisture and energy source is important (Chen and Hoff, 2009). More than 90\% of biofiltration problems were attributed to media drying (Goldstein, 1999). Horizontal media beds (up or down flow) or vertical media beds (horizontal flow) can be used, depending on surface area and space availability (Nicolai and Lefers, 2006). Leaving the biofilters open to the atmosphere helps to reduce pressure drops. Up-flow open biofilters can be constructed at a relatively low initial cost for minimum airflows. Higher construction and operating costs will occur if biofilters are designed for high airflows (Schmidt et al., 2004). Pressure drops of less than $60 \mathrm{~N} / \mathrm{m}^{2}$ (Nicolai and Janni, 1998) and media depth of 0.25 to $0.45 \mathrm{~m}$ (Schmidt et al., 2004) have been suggested to maintain reasonable fan ventilation efficiency and to prevent excessive drying.
Wet scrubbers have been developed for removing dust and air emissions from ventilation fan exhausts. A scrubber consists of a reactor with a filter made from an inert material (e.g., plastic) with large surface area (Botermans et al., 2010). The filter is moistened with a sprayer or sprinkler system. Usually, portion of the used water is recycled and the rest is replaced with new water. Exhaust air is forced through the filter to ensure good contact between air and water. The simplest scrubber uses only water, while acid can be added into the recirculated water to improve reduction of $\mathrm{NH}_{3}$ and make an acid scrubber. Acid scrubbers can reduce $70 \%$ to over $90 \% \mathrm{NH}_{3}$ (Melse and Ogink, 2005; Estelles et al., 2011), but they are much less effective in reducing typical odors (overall average of $27 \%$ reduction; Melse and Ogink, 2005). Effectiveness in reducing $\mathrm{NH}_{3}$ depends on the amount of acid used and the contact time allowed between air and liquid, while effectiveness in reducing odor also depends on the solubility of odorants (Riskowski, 2003). A well designed bio-scrubber that allows the growth of microorganisms participating in the reduction of pollutants and thus can be more efficient in reducing odor as compared to acid scrubber although it may emit more microorganisms and may be less efficient in reducing $\mathrm{NH}_{3}$ (Melse and Ogink, 2005; Zhao et al., 2011). Research is ongoing to develop multi-stage scrubbers that are effective in reducing multipollutants with minimized water consumption and optimized microbiological processes (Zhao et al., 2011; Ogawa et al., 2011). Wet scrubbers have great potential for adaptation to existing swine facility ventilation fans because they do not cause excessive backpressure to the fans and do not significantly reduce building ventilation airflow (Manuzon et al., 2007). One option for decreasing operation costs is to clean only part of the outgoing air, especially for the limited number of days of maximum ventilation (Melse et al., 2006; Botermans et al., 2010). The wet scrubbers can be optimized to benefit both emissions and indoor air quality, and it may also help cool the air (Groenestein et al., 2011). Removed liquid may potentially be used as a liquid fertilizer.

Vegetative environmental buffers (VEBs) can be established by planting trees around swine facilities. VEBs are thought to reduce dust and odor in two ways. First,

Table 6. Effectiveness of biofilters for reducing odor, $\mathrm{H}_{2} \mathrm{~S}$, and $\mathrm{NH}_{3}$ emissions.

\begin{tabular}{|c|c|c|c|c|}
\hline \multirow[b]{2}{*}{ References } & \multirow[b]{2}{*}{ Description of Biofilters ${ }^{[\mathrm{a}]}$} & \multicolumn{3}{|c|}{ Reduction in Emissions } \\
\hline & & Odor $(\%)$ & $\mathrm{H}_{2} \mathrm{~S}(\%)$ & $\mathrm{NH}_{3}(\%)$ \\
\hline Akdeniz and Janni, 2012 & Flat-bed, depth $=0.3 \sim 0.4 \mathrm{~m}$, EBRT $=5 \sim 7 \mathrm{~s}$. & - & $49 \sim 85$ & $53 \sim 86$ \\
\hline Chen and Hoff, 2012 & Wood chip-based, moisture $=72 \%$, EBRT $=3.7 \sim 5.5 \mathrm{~s}$. & 51 & 83 & 41 \\
\hline Lim et al., 2012 & $\begin{array}{l}\text { Wood chip-based, depth }=1.27 \sim 2.54 \mathrm{~m}, \text { EBRT }=0.3 \sim 0.6 \mathrm{~s}, \\
\text { pressure drop }=29.6 \sim 57.2 \mathrm{~N} / \mathrm{m}^{2} .\end{array}$ & - & $23.6 \sim 42.4$ & $18.1 \sim 45.8$ \\
\hline Chen et al., 2009 & Wood chip-based, moisture $=60 \%$, EBRT $=1.6 \sim 7.3 \mathrm{~s}$ & $70.1 \sim 82.3$ & $81.8 \sim 88.6$ & $43.4 \sim 74$ \\
\hline Nicolai et al., 2006 & $\begin{array}{l}50: 50 \text { mixture of yard waste compost and wood chips, moisture }=40 \sim 60 \% \text {, } \\
\text { EBRT }=5 \mathrm{~s} .\end{array}$ & - & - & $76.7 \sim 82.3$ \\
\hline Chang et al., 2004 & $70: 30$ mixture of pine and perlite, moisture $=60 \sim 80 \%$, EBRT $=\sim 10 \mathrm{~s}$ & - & 82.4 & 95.6 \\
\hline Sheridan et al., 2002 & $\begin{array}{l}\text { Wood chip-based, moisture }=64 \sim 69 \%, \mathrm{pH}=6 \sim 8, \text { pressure drop }=14 \sim 64 \mathrm{~N} / \mathrm{m}^{2} \text {, } \\
\text { EBRT }=2 \sim 5 \mathrm{~s} .\end{array}$ & 77 95 & - & $54 \sim 93$ \\
\hline Hartung et al., 2001 & Coconut fiber and peat fiber mixture, EBRT $=3 \sim 40 \mathrm{~s}$ & $78 \sim 80$ & - & $15 \sim 36$ \\
\hline Nicolai and Janni, 2001 & 70:30 mixture of wood chips and compost, moisture $=54.7 \%$. & Up to 78.8 & Up to 87 & Up to 81 \\
\hline Sun et al., 2000 & $\begin{array}{l}\text { Mixture of wood chips and compost, moisture }=30 \sim 50 \%, \text { EBRT }=5 \sim 20 \mathrm{~s} . \\
\text { Mixture of wood chips and compost, moisture }=50 \%, \text { EBRT }=20 \mathrm{~s} .\end{array}$ & - & $\begin{array}{l}47 \sim 94 \\
93 \sim 94 \\
\end{array}$ & $\begin{array}{l}25 \sim 90 \\
76 \sim 90 \\
\end{array}$ \\
\hline Nicolai and Janni, 1997 & Compost/bean straw, EBRT $=8.8 \mathrm{~s}$, pressure drop $=25 \sim 47 \mathrm{~N} / \mathrm{m}^{2}$ & 78 & 86 & 50 \\
\hline
\end{tabular}

[a] EBRT $=$ Empty bed residence time. 
VEBs work as a windbreak, enhancing vertical air mixing that results in more dilution, and slowing air movement that results in more deposition of dust. Second, VEBs reduce odor and dust as living bio-filters through interception and retention of dust, and adsorption and break down of odor components. The surface cuticle which covers the epidermis of leaves of vascular plants has an affinity for Nbased chemicals (Walter, 2010). VEBs have been shown to reduce downwind concentrations (up to $50 \%$ reduction in $\mathrm{NH}_{3}$ and dust; up to $85 \%$ reduction in $\mathrm{H}_{2} \mathrm{~S}$; and $6 \%$ to $66 \%$ reduction in odor; table 7). Effectiveness and costs are highly variable and depend on site-specific design. The most effective reduction occurs just beyond the VEBs (Lin et al., 2006; Nicolai et al., 2010; Parker et al., 2012). Wind tunnel simulation on roadside barriers showed that percentage reduction in air pollutants decreased with downwind distance and was generally below $50 \%$ beyond distances of 15 times of the barrier height (Heist, 2009). Greater species diversity and a combination of plant growth rates are recommended to make a robust and mature VEB system (NRCS, 2007; Tyndall, 2008). A row spacing of 5 to $7 \mathrm{~m}$ (16 to $20 \mathrm{ft}$ ) is recommended by the Natural Resource and Conservation Service. Design of VEBs should consider air circulation near and through animal houses. Minimum distances of $23 \mathrm{~m}$ (75 ft) from a swine house are recommended for mechanical ventilation and 30 $\mathrm{m}(100 \mathrm{ft})$ for natural ventilation (May, 2011). VEBs are gaining popularity as a promising strategy for mitigating dust, odor, $\mathrm{NH}_{3}$, and $\mathrm{H}_{2} \mathrm{~S}$ from farms. Additional advantages of VEBs include visual screen (aesthetics value), snow fences, improved neighbor relations, and increased effectiveness over time. The main barrier to adoption of VEBs is lack of information on technical guidelines and the length of time it may take to develop a mature VEB system. Appropriate site preparation is critical to the long-term health of tree plantings and will contribute to lower tree mortality and faster tree growth. Many problems of VEBs (e.g., high tree mortality) were due to inadequate site preparation (Tyndall, 2008).

Oil spraying/sprinkling on floor and pen surfaces at regular intervals has been shown to reduce dust levels in swine buildings up to $46 \%$ (Banhazi, 2005) and thus can potentially reduce odor (Chastain, 1999). Zhang et al. (1997) observed a $27 \%$ reduction in $\mathrm{H}_{2} \mathrm{~S}$ and a $30 \%$ reduction in $\mathrm{NH}_{3}$ concentrations with canola oil sprinkling. Kim et al. (2008) found the essential oil had a significant effect on reducing sulfuric odorous compounds for $24 \mathrm{~h}$ after spraying. However, problems such as oils transforming into a gum and plugging irrigation sprinklers have been observed during manure application (Riskowski, 2003). Smaller facilities could apply the oil with a hand sprayer. The oil needs to be applied at low pressure to form relatively large droplets and avoid formation of a fine mist that gets into the worker's and animal's respiratory systems (Zhang, 1997).

Photo-catalysis can be defined as a chemical reaction influenced or initiated by light. Titanium dioxide $\left(\mathrm{TiO}_{2}\right)$ has been widely used as photocatalyst. When a $\mathrm{TiO}_{2}$ treated surface is irradiated with UV-light, an electron-hole pair is created and the hole generates highly reactive hydroxyl radicals, which can oxidize and break down many organic and inorganic air pollutants, including $\mathrm{NH}_{3}, \mathrm{NO}_{\mathrm{x}}$, $\mathrm{H}_{2} \mathrm{~S}$, VOC, and $\mathrm{CH}_{4}$ (Guarino, et al., 2008; Koziel, et al., 2008). The use of photocatalytic processes using $\mathrm{UV} / \mathrm{TiO}_{2}$ for treating livestock emissions has great prospects as it destroys many harmful organic pollutants at significant rates, and the process destroys bacteria and viruses (Maness et al., 1999; Costaet al., 2012), and it can be used for treating exhaust air as well as indoor air. Livestock odor can be mitigated into less odorous or odorless products such as $\mathrm{CO}_{2}$ and water. Guarino et al. (2008) placed $12 \mathrm{UV}$ lamps (36 W, 315 400 nm) in a 30-head farrowing house with inside wall coated with $\mathrm{TiO}_{2}$ paint, and they observed $\mathrm{NH}_{3}$ concentrations were reduced by $30 \% \quad(\mathrm{P}<0.001)$ compared with control room. Research on the photocatalytic technology is ongoing to realize its potential to become a low-cost alternative to other mitigation technologies.

\section{CONCLUSION}

The practices and technologies discussed vary in cost and effectiveness. Due to the small profit margins in the swine industry, options for odor control need to be very cost effective to be favored. Diet modification strategies have been shown to reduce $\mathrm{NH}_{3}$ emissions effectively with low cost, and should be considered as best management practices, although their effectiveness in reducing odor is still uncertain. Permeable covers and biofilters seem to have great potential to be the most promising and cost effective technologies for manure storage facilities and swine houses, respectively. However, both of the technologies need careful maintenance to perform effectively. Care must be taken to select technologies that are compatible with the management capabilities of the

Table 7. Effectiveness of VEBs for reducing odor, $\mathrm{H}_{2} \mathrm{~S}$ and $\mathrm{NH}_{3}$ emissions.

\begin{tabular}{|c|c|c|}
\hline References & Description of VEBs & Reduction in Emissions \\
\hline Hernandez et al., 2012 & $\begin{array}{l}\text { Single row of Austree willow, } \\
52 \sim 100 \mathrm{~m} \text { from house, } 9 \mathrm{~m} \text { tall }\end{array}$ & $40 \sim 60 \%$ reduction in odor compounds \\
\hline Parker et al., 2012 & Five rows, $9 \sim 12 \mathrm{~m}$ from fans, $2.4 \sim 3.6 \mathrm{~m}$ tall & $\begin{array}{l}66.3 \% \text { reduction in odor at } 15 \mathrm{~m} ; \\
\text { no reduction at } 150 \mathrm{~m} \text { and } 300 \mathrm{~m} \text { downwind }\end{array}$ \\
\hline Nicolai et al., 2010 & One to three rows & $\begin{array}{l}\text { Most effective reduction occurs just } \\
\text { beyond VEB; little effect after } 500 \mathrm{~m}\end{array}$ \\
\hline Tyndall, 2008 & - & $\begin{array}{l}6 \sim 15 \% \text { reduction in odor, } \\
\text { up to } 50 \% \text { reduction in } \mathrm{NH}_{3} \text { and dust }\end{array}$ \\
\hline Lin et al., 2006 & $\begin{array}{c}\text { Single row, } 15 \sim 60 \mathrm{~m} \text { from odor generator, } \\
7.6 \sim 18.3 \mathrm{~m} \text { tall }\end{array}$ & $\begin{array}{c}\text { Reduction in odor: } 68 \% \text { at } 117 \mathrm{~m} \text { downwind; } \\
3 \% \text { at } 520 \mathrm{~m} \text { downwind }\end{array}$ \\
\hline Nicolai et al., 2004b & $\begin{array}{l}\text { The mature VEB: } 8 \text { rows, } 1.8 \mathrm{~m} \text { from manure storage, } \\
9 \mathrm{~m} \text { tall, } 42 \mathrm{~m} \text { in depth; the immature VEB: } 2 \text { rows }\end{array}$ & $\begin{array}{l}85 \% \text { reduction in } \mathrm{H}_{2} \mathrm{~S} \text { for the mature } \mathrm{VEB} \text {; reduction in } \mathrm{H}_{2} \mathrm{~S} \\
\text { was significant only at } \mathrm{V}<5 \mathrm{mph} \text { for the immature VEB }\end{array}$ \\
\hline
\end{tabular}


operation to prevent potential failure due to mismanagement. Some technologies have not been evaluated thoroughly, and some may need more economic incentives or regulatory compliance requirements to be widely adopted. For storage additives, more research is needed to understand the mechanisms and to improve reliability; for solid-liquid separation, more research is needed to develop practical techniques for immediate separation of solids from freshly excreted manure; for wet scrubbers, more research is needed to optimize microbiological processes and to minimize water consumption. When trying to control odor, one should consider the whole farm system. No single method will completely eliminate odors from swine facilities, so a combination of different practices and technologies is recommended. For example, the odor from swine houses can be reduced by a combination of dietary modification and biofilter installation, while odor from storage facilities can be reduced by installing a permeable cover and/or a VEB. In larger operations similar practices and technologies may be combined with a manure separator and/or a digester.

\section{REFERENCES}

Aarnink, A. J. A., \& Verstegen, M. W. A. (2007). Nutrition, key factor to reduce environmental load from pig production. Livestock Sci., 109(1), 194-203. doi:http://dx.doi.org/10.1016/j.livsci.2007.01.112

Aarnink, A. J. A., Hol, J. M. G., \& Nijeboer, G. M. (2008). Ammonia emission factor for using benzoic acid ( $1 \%$ vevovitall) in the diet of growing-finishing pigs. Lelystad, The Netherlands: Animal Sciences Group, Divisie Veehouderij.

Akdeniz, N., \& Janni, K. A. (2012). Full-scale biofilter reduction efficiencies assessed using portable 24-hour sampling units. $J$. Air Waste Mgmt. Assoc., 62(2), 170-182. doi:http://dx.doi.org/10.1080/10473289.2011.639479

Alpine, P. O., O'Shea, C. J., Varley, P. F., Solan, P., Curran, T., \& O'Doherty, J. V. (2012). The effect of protease and nonstarch polysaccharide enzymes on manure odor and ammonia emissions from finisher pigs. J. Animal Sci., 90(Suppl. 4), 369371. doi:http://dx.doi.org/10.2527/jas.53948

Andersson, M. (1995). The effect of different manuring systems on ammonia emissions in pig buildings. Report 100. Lund, Sweden: Swedish Univ. Agricultural Sciences, Dept. Agricultural Biosystems and Technology.

Andersson, M. (1998). Reducing ammonia emissions by cooling of manure culverts. Nutrient Cycling in Agroecosys., 51(1), 73-79. doi:http://dx.doi.org/10.1023/A:1009755311356

Astals, S., Nolla, A., \& Mata-Alvarez, J. (2012). Anaerobic codigestion of pig manure and crude glycerol at mesophilic conditions: Biogas and digestate. Bioresource Tech., 110, 63-70. doi:http://dx.doi.org/10.1016/j.biortech.2012.01.080

Bakker, G. C., \& Smits, M. C. (2002). Dietary factors are additive in reducing in vitro ammonia emissions from pig manure. $J$. Animal Sci., 79(Suppl. 1), 753.

Banhazi, T. (2005). Oil spraying systems for piggeries to control dust. In T. Fahy (Ed.), Proc. AAPV Conf. AVA, Gold Coast, QLD, Australia. (pp. 76-80).

Banhazi, T., Hudson, N., Dunlop, M., Dyson, C., \& Thomas, R. (2009). Development and testing of an evaluation procedure for commercial manure additive products. Biosyst. Eng., 103(3), 321-328. doi:http://dx.doi.org/10.1016/j.biosystemseng. 2009.04.011
Bicudo, J. R., Clanton, C. J., Schmidt, D. R., Powers, W., Jacobson, L. D., \& Tengman, C. L. (2004). Geotextile covers to reduce odor and gas emissions from swine manure storage ponds. Applied Eng. in Agric., 20(1), 65-75. doi:http://dx.doi.org/10.13031/2013.15685

Bicudo, J. R., Schmidt, D. R., \& Jacobson, L. D. (2003). Using covers to minimize odor and gas emissions from manure storages. Lexington, Ky.: Cooperative Ext. Service, Univ. Kentucky.

Blanes-Vidal, V., Hansen, M. N., \& Sousa, P. (2009). Reduction of odor and odorant emissions from slurry stores by means of straw covers. J. Environ. Qual., 38(4), 1518-1527. doi:http://dx.doi.org/10.2134/jeq2008.0412

Botermans, J., Gustafsson, G., Jeppsson, K. H., Brown, N., \& Rodhe, L. (2010). Measures to reduce ammonia emissions in pig production: Review. Report 2010:12. Uppsala, Sweden: Swedish Univ. Agricultural Sciences.

Bottcher, R. W. (2001). An environmental nuisance: Odor concentrated and transported by dust. Chem. Senses, 26(3), 327331. doi:http://dx.doi.org/10.1093/chemse/26.3.327

Braam, C., \& Swierstra, D. (1999). Volatilization of ammonia from dairy housing floors with different surface characteristics. $J$. Agric. Eng. Res., 72(1), 59-69. doi:http://dx.doi.org/10.1006/jaer.1998.0345

Canh, T. T., Aarnink, A. J. A., Schutte, J. B., Sutton, A. L., Langhout, D. J., \& Schrama, J. W. (1998). Dietary protein affects nitrogen excretion and ammonia emission from slurry of growing-finishing pigs. Livestock Prod. Sci., 56(3), 181-191. doi:http://dx.doi.org/10.1016/S0301-6226(98)00156-0

Chang, D. I., Lee, S. J., Choi, W. Y., \& Lee, S. K. (2004). A pilotscale biofilter system to reduce odor from swine operation. ASAE Paper No. 044056. St. Joseph, Mich.: ASAE.

Chantigny, M. H., MacDonald, J. D., Beaupré, C., Rochette, P., Angers, D. A., Massé, D., \& Parent, L.-E. (2009). Ammonia volatilization following surface application of raw and treated liquid swine manure. Nutrient Cycling in Agroecosys., 85(3), 275-286. doi:http://dx.doi.org/10.1007/s10705-009-9266-7

Chastain, J. P. (1999). Air Quality and Odor Control from Swine Production Facilities. Confined Animal Manure Managers Program. Chapter 9. Clemson, S.C.: Clemson Univ. Extension. Retrieved from http://www.clemson.edu/extension/livestock/ camm/camm_files/swine/sch9_03.pdf

Chen, L., \& Hoff, S. J. (2009). Mitigating odors from agricultural facilities: a review of literature concerning biofilters. Applied Eng. in Agric., 25(5), 751-766. doi:http://dx.doi.org/10.13031/2013.28854

Chen, L., \& Hoff, S. J. (2012). A two-stage wood chip-based biofilter system to mitigate odors from a deep-pit swine building. Applied Eng. in Agric., 28(6), 893-901. doi:http://dx.doi.org/10.13031/2013.42476

Chen, L., Hoff, S. J., Cai, L., Koziel, J., \& Zelle, B. (2009). Evaluation of wood chip-based biofilters to reduce odor, hydrogen sulfide, and ammonia from swine barn ventilation air. J. Air Waste Mgmt. Assoc., 59(5), 520-530. doi:http://dx.doi.org/10.3155/1047-3289.59.5.520

Childers, J. W., Thompson Jr., E. L., Harris, D. B., Kirchgessner, D. A., Clayton, M., Natschke, D. F., \& Phillips, W. J. (2001). Multi-pollutant concentration measurements around a concentrated swine production facility using open-path FTIR spectrometry. Atmospheric Environ., 35(11), 1923-1936.

Cho, J. H., Chen, Y. J., Min, B. J., Yoo, J. S., Wang, Y., \& Kim, I. H. (2008). Effects of reducing dietary crude protein on growth performance, odor gas emission from manure and blood urea nitrogen and IGF-1 concentrations of serum in nursery pigs. Animal Sci. J., 79(4), 453-459. doi:http://dx.doi.org/10.1111/j.1740-0929.2008.00549.x 
Cicek, N., Zhou, X., Zhang, Q., \& Tenuta, M. (2004). Impact of straw cover on greenhouse gas and odor emissions from manure storage lagoons using a flux hood. ASAE Paper No. 044054. St. Joseph, Mich.: ASAE.

Clanton, C. J., Schmidt, D. R., Jacobson, L. D., Nicolai, R. E., Goodrich, P. R., \& Janni, K. A. (1999). Swine manure storage covers for odor control. Applied Eng. in Agric., 15(5), 567-572. doi:http://dx.doi.org/10.13031/2013.5819

Clanton, C. J., Schmidt, D. R., Nicolai, R. E., Jacobson, L. D., Goodrich, P. R., Janni, K. A., \& Bicudo, J. R. (2001). Geotextile fabric-straw manure storage cover for odor, hydrogen sulfide, and ammonia control. Applied Eng. in Agric., 17(6), 849-858. doi:http://dx.doi.org/10.13031/2013.6839

Clark, O. G., Moehn, S., Edeogu, I., Price, J., \& Leonard, J. (2005). Manipulation of dietary protein and nonstarch polysaccharide to control swine manure emissions. J. Environ. Qual., 34(5), 14611466. doi:http://dx.doi.org/10.2134/jeq2004.0434

Costa, A., Chiarello, G. L., Selli, E., \& Guarino, M. (2012). Effects of $\mathrm{TiO}_{2}$ based photocatalytic paint on concentrations and emissions of pollutants and on animal performance in a swine weaning unit. J. Environ. Mgmt., 96(1), 86-90. doi:http://dx.doi.org/10.1016/j.jenvman.2011.08.025

Dai, X. R., \& Blanes-Vidal, V. (2013). Emissions of ammonia, carbon dioxide, and hydrogen sulfide from swine wastewater during and after acidification treatment: Effect of $\mathrm{pH}$, mixing and aeration. J. Environ. Mgmt., 115, 147-154.

Doorn, M. R. J., Natschke, D. F., Thorneloe, S. A., \& Southerland, J. (2002). Development of an emission factor for ammonia emissions from US swine farms based on field tests and application of a mass balance method. Atmospheric Environ., 36(36-37), 5619-5625. doi:http://dx.doi.org/10.1016/S13522310(02)00689-1

Eriksen, J., Sørensen, P., \& Elsgaard, L. (2008). The fate of sulfate in acidified pig slurry during storage and following application to cropped soil. J. Environ. Qual., 37(1), 280-286. doi:http://dx.doi.org/10.2134/jeq2007.0317

Estelles, F., Melse, R. W., Ogink, N. W. M., \& Calvet, S. (2011). Evaluation of the $\mathrm{NH}_{3}$ removal efficiency of an acid packed bed scrubber using two methods: A case study in a pig facility. Trans. ASABE, 54(5), 1905-1912. doi:http://dx.doi.org/10.13031/2013.39831

Feilberg, A., Liu, D., Adamsen, A. P. S., Hansen, M. J., \& Jonassen, K. E. N. (2010). Odorant emissions from intensive pig production measured by online proton-transfer-reaction mass spectrometry. Environ. Sci. Tech., 44(15), 5894-5900. doi:http://dx.doi.org/10.1021/es100483s

Gatel, F., \& Grosjean, F. (1992). Effect of protein content of the diet on nitrogen excretion by pigs. Livestock Prod. Sci., 31(1-2), 109120. doi:http://dx.doi.org/10.1016/0301-6226(92)90059-D

Godbout, S., Lemay, S. P., Duchaine, C., Pelletier, F., Larouch, J. P., Belzile, M., \& Feddes, J. J. R. (2009). Swine production impact on residential ambient air quality. J. Agromedicine, 14(3), 291-298. doi:http://dx.doi.org/10.1080/10599240903041943

Goldstein, N. (1999). Longer life for biofilters. BioCycle, 40(7), 62. Govere, E. M., Tonegawa, M., Bruns, M. A., Wheeler, E. F., Kephart, K. B., Voigt, J. W., \& Dec, J. (2007). Using minced horseradish roots and peroxides for the deodorization of swine manure: A pilot scale study. Bioresoure Tech., 98(6), 11911198. doi:http://dx.doi.org/10.1016/j.biortech.2006.05.012

Gralapp, A. K., Powers, W. J., Faust, M. A., \& Bundy, D. S. (2002). Effects of dietary ingredients on manure characteristics and odorous emissions from swine. J. Animal Sci., 80(6), 1512-1519.
Groenestein, C. M., Smits, M. C. J., Huijsmans, J. F. M., \& Oenema, O. (2011). Measures to reduce ammonia emissions from livestock manures: Now, soon and later. Wageningen UR Livestock Research. Report 488. Wageningen, The Netherlands.

Guarino, M., Costa, A., \& Porro, M. (2008). Photocatalytic $\mathrm{TiO}_{2}$ coating-To reduce ammonia and greenhouse gases concentration and emission from animal husbandries. Bioresource Tech., 99(7), 2650-2658. doi:http://dx.doi.org/10.1016/j.biortech.2007.04.025

Guarino, M., Fabbri, C., Brambilla, M., Valli, L., \& Navarotto, P. (2006). Evaluation of simplified covering systems to reduce gaseous emissions from livestock manure storage. Trans. ASABE, 49(3), 737-747. doi:http://dx.doi.org/10.13031/2013.20481

Guo, H., Jacobson, L. D., Schmidt, D. R., Nicolai, R. E., \& Janni, K. A. (2004). Comparison of five models for setback distance determination from livestock sites. Canadian Biosyst. Eng., 46(6), 17-25.

Guo, H., Jacobson, L. D., Schmidt, D. R., Nicolai, R. E., Zhu, J., \& Janni, K. A. (2005). Development of the offset model for determination of odor-annoyance-free setback distances from animal production sites: Part II. Model development and evaluations. Trans. ASAE, 48(6), 2269-2276. doi:http://dx.doi.org/10.13031/2013.20090

Hamon, L., Andrès, Y., \& Dumont, E. 2012 Aerial pollutants in swine buildings: A review of their characterization and methods to reduce them.. Environ. Sci. Tech., 46(22), 12287-12301. doi:http://dx.doi.org/10.1021/es3025758

Hanni, S. M., DeRouchey, J. M., Tokach, M. D., Goodband, R. D., Nelssen, J. L., \& Dritz, S. S. (2007). The effects of dietary chicory and reduced nutrient diets on composition and odor of stored swine manure. Prof. Animal Sci., 23, 438-447.

Hansen, K. H., Angelidaki, I., \& Ahring, B. K. (1998). Anaerobic digestion of swine manure: Inhibition by ammonia. Water Res., 32(1), 5-12. doi:http://dx.doi.org/10.1016/S00431354(97)00201-7

Hansen, M. N., Kai, P., \& Maller, H. B. (2006). Effects of anaerobic digestion and separation of pig slurry on odor emission. Applied Eng. in Agric., 22(1), 135-139. doi:http://dx.doi.org/10.13031/2013.20192

Hartung, E., Jungbluth, T., \& Busche, W. (2001). Reduction of ammonia and odor emissions from a piggery with biofilters. Trans. ASAE, 44(1), 113-118. doi:http://dx.doi.org/10.13031/2013.2302

Hayes, E. T., Leek, A. B. G., Curran, T. P., Dodd, V. A., Carton, O. T., Beattie, V. E., \& O'Doherty, J. V. (2004). The influence of diet crude protein level on odour and ammonia emissions from finishing pig houses. Bioresource Tech., 91(3), 309-315. doi:http://dx.doi.org/10.1016/S0960-8524(03)00184-6

Heber, A. J., Lim, T. T., Ni, J. Q., \& Sutton, A. L. (2000b). Odor and gas emission from anaerobic treatment of swine manure. Indianapolis, Ind.: Indiana's Value-Added Agricultural Grant Program.

Heber, A. J., Ni, J. Q., Lim, T. T., Diehl, C. A., Sutton, A. L., Duggirala, R. K., Haymore, B. L., Kelly, D. T., \& Adamchuk, V. I. (2000a). Effect of a manure additive on ammonia emission from swine finishing buildings. Trans. ASAE, 43(6), 1895-1902. doi:http://dx.doi.org/10.13031/2013.3094

Heber, A. J. (2010). Final Reports of the National Air Emissions Monitoring Study. Available at http://www.epa.gov/airquality/agmonitoring/data.html. Accessed June 2014.

Heist, D. K., Perry, S. G., \& Brixey, L. A. (2009). A wind tunnel study of the effect of roadway configurations on the dispersion of traffic-related pollution. Atmospheric Environ., 43(32), 51015111. doi:http://dx.doi.org/10.1016/j.atmosenv.2009.06.034 
Hernandez, F., Martinez, S., Lopez, C., Megias, M. D., Lopez, M., \& Madrid, J. (2011). Effect of dietary crude protein levels in a commercial range, on the nitrogen balance, ammonia emission and pollutant characteristics of slurry in fattening pigs. Animal, 5(8), 1290-1298.

doi:http://dx.doi.org/10.1017/S1751731111000115

Hernandez, G., Trabuea, S., Sauer, T., Pfeiffer, R., \& Tyndall, J. (2012). Odor mitigation with tree buffers: Swine production case study. Agric. Ecosyst. Environ., 149, 154-163. doi:http://dx.doi.org/10.1016/j.agee.2011.12.002

Hoff, S. J., Bundy, D. S., \& Harmon, J. R. (2008). Modeling receptor odor exposure from swine production sources using CAM. Appleid Eng. in Agric., 24(6), 821-837. doi:http://dx.doi.org/10.13031/2013.25369

Hoff, S. J., Harmon, J. R., Bundy, D. S., \& Zelle, B. C. (2009). Source and receptor ammonia and hydrogen sulfide concentrations in communities with and without swine emission sources: Follow-up study. Appleid Eng. in Agric., 25(6), 975986. doi:http://dx.doi.org/10.13031/2013.29235

Hornig, G., Turk, M., \& Wanka, U. (1999). Slurry covers to reduce ammonia emission and odor nuisance. J. Agric. Eng. Res., 73(2), 151-157. doi:http://dx.doi.org/10.1006/jaer.1998.0402

Huang, C., Li, J., Kang, W., \& Tang, X. (2006). Effect of adding Lactobacillus plantarum and soluble carbohydrates to swine manure on odorous compounds, chemical composition and indigenous flora. J. Environ. Sci., 18(1), 201-206.

Hudson, N., Ayoko, G. A., Collman, G., Gallagher, E., Dunlop, M., \& Duperouzel, D. (2008). Long-term assessment of efficacy of permeable pond covers for odour reduction. Bioresoure Tech., 99(14), 6409-6418. doi:http://dx.doi.org/10.1016/j.biortech.2007.11.058

Hudson, N., Duperouzel, D., \& Melvin, S. (2006a). Assessment of permeable covers for odor reduction in piggery effluent ponds. 1. Laboratory-scale trials. Bioresource Tech., 97(16), 20022014. doi:http://dx.doi.org/10.1016/j.biortech.2005.11.002

Hudson, N., Gies, A., \& Duperouzel, D. (2006b). Assessment of permeable covers for odor reduction in piggery effluent ponds. 2. Field-scale trials. Bioresource Tech., 97(16), 2015-2023. doi:http://dx.doi.org/10.1016/j.biortech.2005.11.015

Jacobson, L. D. (2011). Energy and ventilation management issues in U.S. pig buildings. Exploring the Future Proceedings of the $11^{\text {th }}$ London Swine Conference. London, Ontario, Canada. Retrieved from http://www.londonswineconference.ca/ proceedings/2011/1sc2011.pdf

Jacobson, L. D., Guo, H., Schmidt, D. R., Nicolai, R. E., Zhu, J., \& Janni, K. A. (2005). Development of the offset model for determination of odor-annoyance-free setback distances from animal production sites: Part I. Review and experiment. Trans. ASAE, 48(6), 2259-2268. doi:http://dx.doi.org/10.13031/2013.20089

Jacobson, L. D., Schmidt, D. R., Lake, J. K., \& Johnson, V. J. (2003). Ammonia, hydrogen sulfide, odor, and PM10 emissions from deep-bedded hoop and curtain-sided pig finishing barns in Minnesota. Air Pollution from Agricultural Operations III, (pp. 283-291). Proceedings of the 12-15 October 2003 Conference. Research Triangle Park, North Carolina, USA. ASAE publication number 701P1403.

Kai, P., Pedersen, P., Jensen, J. E., Hansen, M. N., \& Sommer, S. G. (2008). In A whole-farm assessment of the efficacy of slurry acidification in reducing ammonia emissions. European $J$. Agron., 28(2), 148-154. doi:http://dx.doi.org/10.1016/j.eja.2007.06.004

Karlsson, S. 1996. Measures to reduce ammonia losses from storage containers for liquid manure. Report No 96E-013. Presented at AgEng Intl. Conf. Madrid, Spain. 23-26 September 1996.
Kay, R. M., \& Lee, P. A. (1997). Ammonia emission from pig buildings and characteristics of slurry produced by pigs offered low crude protein diets. Proc. Symp. Ammonia and Odor Control from Animal Production Facilities. Vinkeloord, The Netherlands.

Kendall, D. C., Lemenager, K. M., Richert, B. T., Sutton, A. L., Frank, J. W., Belstra, B. A., \& Bundy, D. (1998). Effects of intact protein diets versus reduced crude protein diets supplemented with synthetic amino acids on pig performance and ammonia levels in swine buildings. Swine Day (pp. 141146). Purdue University

Kendall, D. C., Richert, B. T., Sutton, A. L., Frank, J. W., \& de Camp, S. A. (1999). Effects of fiber addition (10\% soybean hulls) to a reduced crude protein diet supplemented with synthetic amino acids versus a standard commercial diet on pig performance, pit composition, odor and ammonia levels in swine buildings. Swine Day (pp. 46-52). Purdue University.

Kim, I. B., Ferket, P. R., Powers, W. J., Stein, H. H., \& VanKempen, T. A. T. G. (2004). Effects of different dietary acidifier sources of calcium and phosphorus on ammonia, methane and odorant emission from growing-finishing pigs. Asian-Australasian. J. Animal Sci., 17, 1131-1138.

Kim, J. C., Simmins, P. H., Mullan, B. P., \& Pluske, J. R. (2005). The digestible energy value of wheat for pigs, with special reference to the post-weaned animal. Animal Feed Sci. Tech., 122(3), 257-287. doi:http://dx.doi.org/10.1016/j.anifeedsci.2005.02.022

Kim, K. Y., Ko, H. J., Kim, H. T., Kim, Y. S., Roh, Y. M., Lee, C. M., \& Kim, C. N. (2008). Odor reduction rate in the confinement pig building by spraying various additives. Bioresoure Tech., 99(17), 8464-8469. doi:http://dx.doi.org/10.1016/j.biortech.2007.12.082

Koziel, J., Yang, X., Cutler, T., Zhang, S., Zimmerman, J., Hoff, S., Jenks, W., Van Leeuwen, H., Laor, Y., Ravid, U., \& Armon, R. (2008). Mitigation of odor and pathgens from CAFOs with $\mathrm{UV} / \mathrm{TIO}_{2}$ : Exploring cost effectiveness. Proc. Mitigating Air Emissions from Animal-Feeding Operations Conf.

Kroodsma, W. (1985). Separation as a method of manure handling and odors reduction in pig buildings. In Odor Prevention and Control of Organic Sludge and Livestock Farming. London, U.K.: Elsevier Applied Science Publ.

Le, P. D., Aarnink, A. J. A., \& Jongbloed, A. W. (2009). Odour and ammonia emission from pig manure as affected by dietary crude protein level. Livestock Sci., 121(2), 267-274. doi:http://dx.doi.org/10.1016/j.livsci.2008.06.021

Le, P. D., Aarnink, A. J. A., Jongbloed, A. W., van der Peet Schwering, C. M. C., Ogink, N. W. M., \& Verstegen, M. W. (2007a). Effects of crystalline amino acid supplementation to the diet on odor from pig manure. J. Animal Sci., 85(3), 791-801. doi:http://dx.doi.org/10.2527/jas.2006-644

Le, P. D., Aarnink, A. J. A., Jongbloed, A. W., Van der PeetSchwering, C. M. C., Ogink, N. W. M., \& Verstegen, M. W. A. (2008). Interactive effects of dietary crude protein and fermentable carbohydrate levels on odor from pig manure. Livestock Sci., 114(1), 48-61. doi:http://dx.doi.org/10.1016/j.livsci.2007.04.009

Le, P. D., Aarnink, A. J. A., Jongbloed, A. W., Van der PeetSchwering, C. M. C., Ogink, N. W. M., \& Verstegen, M. W. A. (2007b). Effects of dietary crude protein level on odour from pig manure. Animal, 1(5), 734-744. doi:http://dx.doi.org/10.1017/S1751731107710303

Le, P. D., Aarnink, A. J. A., Ogink, N. W. M., Becker, P. M., \& Verstegen, M. W. A. (2005). Odour from animal production: its relation to die. Nutrition Res. Rev., 18(1), 3-30. doi:http://dx.doi.org/10.1079/NRR200592 
Lee, S. R., Han, J. K., Choi, Y. J., \& Nam, K. (2007). Reduction of ammonia and hydrogen sulfide emission from swine manure using aqueous foams amended with microorganisms and chemical additives. Clean, 35(3), 230-234.

Leek, A. G. B., Callan, J. J., Henry, R. W., \& O'Doherty, J. V. (2005). The application of low crude protein wheat-soyabean diets to growing and finishing pigs. 2 . The effects on nutrient digestibility, nitrogen excretion, faecal volatile fatty acid concentration and ammonia emission from boars. Irish J. Agric. Food Res., 44, 247-260.

Lenis, N. P. (1993). Lower nitrogen excretion in pig husbandry by feeding: Current and future possibilities. Proc. First Intl. Symp. Nitrogen Flow in Pig Production and Environmental Consequences (pp. 61-70). Wageningen, The Netherlands: EAAP.

Lenis, N. P., \& Schutte, B. (1990). Amino acid supply of piglets and grow-finish pigs in relation to nitrogen excretion. In A. Jongbloed, \& J. Coppoolse (Eds.), Manure Issues: Nutritional Solutions for Pigs and Poultry (pp. 79-89). Wageningen, The Netherlands: Service Agricultural Research.

Li, W., Powers, W., \& Hill, G. M. (2011). Feeding distillers dried grains with soluble and organic trace mineral source to swine and the resulting effect on gaseous emission. J. Animal Sci., 89(10), 3286-3299. doi:http://dx.doi.org/10.2527/jas.2010-3611

Lim, T. T., Heber, A. J., \& Ni, J. Q. (2000a). Odor and gas emissions from anaerobic treatment of swine waste. Paper No. 004081. St. Joseph, Mich.: ASABE.

Lim, T. T., Heber, A. J., Ni, J. Q., Grant, R., \& Sutton, A. L. (2000b). Odor impact distance guideline for swine production system. Retrieved from https://engineering.purdue.edu/ jiqin/Publications/Lim2000Odo rVOC.pdf

Lim, T. T., Heber, A. J., Ni, J. Q., Kendall, D. C., \& Richert, B. T. (2004). Effects of manure removal strategies on odor and gas emissions from swine finishing. Trans. ASAE, 47(6), 2041-2050. doi:http://dx.doi.org/10.13031/2013.17801

Lim, T. T., Heber, A. J., Ni, J. Q., Sutton, A. L., \& Kelly, D. T. (2001). Characteristics and emission rates of odor from commercial swine nurseries. Trans. ASABE, 44(5), 1275-1282. doi:http://dx.doi.org/10.13031/2013.6432

Lim, T. T., Heber, A. J., Ni, J. Q., Sutton, A. L., \& Shao, P. (2003). Odor and gas release from anaerobic treatment lagoons for swine manure. J. Environ. Quality, 32(2), 406-416. doi:http://dx.doi.org/10.2134/jeq2003.4060

Lim, T. T., Yaomin, J., Ni, J. Q., \& Heber, A. J. (2012). Field evaluation of biofilters in reducing aerial pollutant emissions from a commercial pig finishing building. Biosystems Eng., 112(3), 192-201. doi:http://dx.doi.org/10.1016/j.biosystemseng.2012.04.001

Lin, X. J., Barrington, S., Nicell, J., Choiniere, D., \& Vezina, A. (2006). Influence of windbreaks on livestock odour dispersion plume in the field. Agric. Ecosyst. Environ., 116(3-4), 263-272. doi:http://dx.doi.org/10.1016/j.agee.2006.02.014

Liu, Z., Powers, W., Murphy, J., \& Maghirang, R. (2013). Ammonia and hydrogen sulfide emissions from swine production facilities in North America: A meta-analysis. $J$. Animal Sci., 92(4), 1-10. doi:http://dx.doi.org/10.2527/jas.20137160

Lupis, S. G., Embertson, N., \& Davis, J. G. (2012). Best management practices for reducing ammonia emissions: Lagoon covers. Fact Sheet No. 1.631B. Colorado State Univ. Extension.

Maness, P. C., Smolinski, S., Blake, D. M., Huang, Z., Wolfrum, E. J., \& Jacoby, W. A. (1999). Bactericidal activity of photo catalytic $\mathrm{TiO}_{2}$ reaction: Toward an understanding of its killing mechanism. Appl. Environ. Microbiol., 65(9), 4094-4098.
Manuzon, R. B., Zhao, L. Y., Keener, H. M., \& Darr, M. J. (2007). A prototype acid spray scrubber for absorbing ammonia emissions from exhaust fans of animal buildings. Trans. ASABE, 50(4), 1395-1407. doi:http://dx.doi.org/10.13031/2013.23628

May, J. (2011). Vegetative buffers to control odors on livestock farms. East Lansing, Mich.: Michigan State Univ. Extension. Available at http://msue.anr.msu.edu/news/vegetative_ buffers_to_control_odors_on_livestock_farms. Accessed June 2014.

McCrory, D. F., \& Hobbs, P. J. (2001). Additives to reduce ammonia and odor emissions from livestock wastes: A review. J. Environ. Quality, 30(2), 345-355. doi:http://dx.doi.org/10.2134/jeq2001.302345x

McGahan, E. J., Nicholas, P. J., Watts, P. J., Galvin, G., Lowe, S., Stepnuk, L. M., \& Casey, K. D. (2001). Tong Park pink pond odor research study. APL Project No. 1628. Toowoomba, Australia: FSA Environmental.

Melse, R. W., \& Ogink, N. W. M. (2005). Air scrubbing techniques for ammonia and odor reduction at livestock operations: Review of on-farm research in the Netherlands. Trans. ASABE, 48(6), 2303-2313. doi:http://dx.doi.org/10.13031/2013.20094

Melse, R. W., Wagenberg, A. V., \& Mosquera, J. (2006). Size reduction of ammonia scrubbers for pig and poultry houses: Use of conditional bypass vent at high air loading rates. Biosystems Eng., 95(1), 69-82. doi:http://dx.doi.org/10.1016/j.biosystemseng.2006.05.006

Miner, J. R., Humenik, F. J., Rice, J. M., Rashash, D. M., Williams, D. M., Robarge, W., Harris, D. B., \& Sheffield, R. (2001). Evaluation of a permeable 2-inch thick polyethylene foam lagoon cover. Proc. Intl. Symp. Addressing Animal Production and Environmental Issues. Raleigh, N.C.: North Carolina State Univ.

Misselbrook, T. H., Webb, J., \& Gilhespy, S. L. (2006). Ammonia emissions from outdoor concrete yards used by livestockQuantification and mitigation. Atmospheric Environ., 40(35), 6752-6763. doi:http://dx.doi.org/10.1016/j.atmosenv.2006.05.077

Mobley, H. L. T., \& Hausinger, R. P. (1989). Microbial urease: Significance, regulation, and molecular characterization. Microbiol. Rev., 53, 85-108.

Mukhtar, S., \& Zhang, R. (1995). Guidelines for minimizing odors in swine operations. Pm-1605. Iowa State Univ. Extension Publication.

Ndegwa, P. M. (2003). Solids separation coupled with batchaeration treatment for odor control from liquid swine manure. $J$. Environ. Sci. Health B, 38(5), 631-643. doi:http://dx.doi.org/10.1081/PFC-120023520

Ndegwa, P. M., Hristov, A. N., Arogo, J., \& Sheffield, R. E. (2008). A review of ammonia emission mitigation techniques for concentrated animal feeding operations. Biosystems Eng., 100(4), 453-469. doi:http://dx.doi.org/10.1016/j.biosystemseng.2008.05.010

Nicolai, D., Ball, J., \& Hofer, B. (2010). Effect of shelterbelts on $\mathrm{H}_{2} \mathrm{~S}$ emissions from swine barns. Air Quality Education in Animal Agriculture Webcast Series. Livestock and Poultry Environmental Learning Center. Retrieved from http://www. extension.org/sites/default/files/w/1/10/10febPPNicolai.pdf

Nicolai, R. E., \& Janni, K. A. (1997). Development of a low-cost biofilter for swine production facilities. ASAE Paper No. 974040. St. Joseph, Mich.: ASAE.

Nicolai, R. E., \& Janni, K. A. (1998). Biofiltration-adaptation to livestock facilities. Proc. USC-TRG Conf. Biofiltration (pp. 99106). Los Angeles, Cal.: Univ. Southern California.

Nicolai, R. E., \& Janni, K. A. (2000). Designing biofilters for livestock facilities. Proc. Second Intl. Conf. Air Pollution from Agricultural Operations. Des Moines, Iowa. 
Nicolai, R. E., \& Janni, K. A. (2001). Biofilter media mixture ratio of wood chips and compost treating swine odors. Water Sci. Tech., 44(9), 261-267.

Nicolai, R. E., \& Lefers, R. M. (2006). Biofilters used to reduce emissions from livestock housing: A literature review. Proc. Workshop on Agricultural Air Quality: State of the Science.

Nicolai, R. E., Clanton, C. J., Janni, K. A., \& Malzer, G. L. (2006). Ammonia removal during biofiltration as affected by inlet air temperature and media moisture content. Trans. ASABE, 49(4), 1125-1138. doi:http://dx.doi.org/10.13031/2013.21730

Nicolai, R. E., Pohl, S., \& Schmidt, D. (2002). Covers for manure storage units. South Dakota State Univ.

Nicolai, R. E., Pohl, S., Lefers, R., \& Dittbenner, A. (2004b). Natural windbreak effect on livestock hydrogen sulfide reduction and adapting an odor model to South Dakota weather conditions. South Dakota State Univ., South Dakota Pork Producers.

Nicolai, R., Schmidt, D., \& Janni, K. (2004a). Biofilter design information. BAEU-18. St. Paul, Minn.: Biosystems and Agricultural Engineering Dept., Univ. Minnesota.

NRCS. (2007). Windbreak plant species for odor management around poultry production facilities. Maryland Plant Materials Tech. Note No. 1. Beltsville, Md.: USDA Natural Resources Conservation Service National Plant Materials Center.

Nykänen, A. M., Hamalainen, N., Kostia, S., Mikola, J., \& Romantschuk, M. (2010). Reduction of odorants in swine manure by carbohydrate and bacterial amendments. J. Environ. Qual., 39(2), 678-685. doi:http://dx.doi.org/10.2134/jeq2008.0530

Obrock, H. C., Miller, P. S., \& Lewis, A. J. (1997). The Effect of reducing dietary crude protein concentration on odour in swine facilities. Nebraska Swine Report. Lincoln, Neb: University of Nebraska-Lincoln.

Ogawa, H., Dahl, P. J., Suzuki, T., Kai, P., \& Takai, H. (2011). A microbiological-based air cleaning system using a two-step process for removal of ammonia in discharge air from a pig rearing building. Biosyst. Eng., 109(2), 108-119. doi:http://dx.doi.org/10.1016/j.biosystemseng.2011.02.007

O'Neill, D. H., \& Phillips, V. R. (1992). A review of the control of odour nuisance from livestock buildings: Part 3. Properties of the odorous substances which have been identified in livestock wastes or in the air around them. J. Agric. Eng. Res., 53, 23-50. doi:http://dx.doi.org/10.1016/0021-8634(92)80072-Z

O'Shea, C. J., Sweeney, T., Lynch, M. B., Gahan, D. A., Callan, J. J., \& J O'Doherty, J. V. (2010). Effect of ß-glucans contained in barleyand oat-based diets and exogenous enzyme supplementation on gastrointestinal fermentation of finisher pigs and subsequent manure odor and ammonia emissions. J. Animal Sci., 88(4), 1411-1420. doi:http://dx.doi.org/10.2527/jas.20092115

Otto, E. R., Yokoyama, M., Von Bermuth, R. D., Van Kempen, T., \& Trottier, N. L. (2003). Ammonia, volatile fatty acids, phenolics and odour offensiveness in manure from growing pigs fed diets reduced in protein concentration. J. Animal Sci., 81, 1754-1763.

Ottosen, L. D. M., Poulsen, H. V., Aa, D., NielsenFinster, K., Nielsen, L. P., \& Revsbech, N. P. (2009). Observations on microbial activity in acidified pig slurry. Biosyst. Eng., 102(3), 291-297. doi:http://dx.doi.org/10.1016/j.biosystemseng.2008.12.003

Panetta, D. M., Powers, W. J., Xin, H., Kerr, B. J., \& Stalder, K. J. (2006). Nitrogen excretion and ammonia emissions from pigs fed modified diets. J. Envir. Quality, 35(4), 1297-1308. doi:http://dx.doi.org/10.2134/jeq2005.0411
Parker, D. B., Malone, G. W., \& Walter, W. D. (2012). Vegetative environmental buffer and exhaust fan deflectors for reducing downwind odor and VOCs from tunnel-ventilated swine barns. Trans ASABE, 55(1), 227-240. doi:http://dx.doi.org/10.13031/2013.41250

Patni, N. K., \& Clarke, S. P. (1991). Transient hazardous conditions in animal buildings due to manure gas released during slurry mixing. Appl. Eng. Agric., 7(4), 478-84. doi:http://dx.doi.org/10.13031/2013.26249

Pedersen, B., \& Ravn, P. (2008). Characteristics of Floors for Pig Pens: Friction, shock absorption, ammonia emission and heat conduction. Agric. Eng. Intl.: CIGR Ejournal, X, Manuscript BC 08005 .

Pepple, L. M., Burns, R. T., Xin, H., Li, H., \& Patience, J. F. (2010). A comparison of gaseous emissions from swine finisher facilities fed traditional vs. a DDGS-based diet. Proc. Intl. Symp. Air Quality and Manure Management for Agriculture. St. Joseph, Mich.: ASABE.

Philippe, F. X., Laitat, M., Canart, B., Farnir, F., Massart, L., Vandenheede, M., \& Nicks, B. (2006). Effects of a reduction of diet crude protein content on gaseous emissions from deep-litter pens for fattening pigs. Animal Res., 55(5), 397-407. doi:http://dx.doi.org/10.1051/animres:2006029

Philippe, F. X., \& Nicks, B. (2013). Emissions of ammonia, nitrous oxide and methane from pig houses: Influencing factors and mitigation techniques. European Workshop: Reconciling the Environment with Livestock Management. Retrieved from http://orbi.ulg.ac.be/bitstream/2268/146949/1/Philippe_PigHousi ng.pdf

Portejoie, S., Dourmad, J. Y., Martinez, J., \& Lebreton, Y. (2004). Effect of lowering crude protein on nitrogen excretion, manure composition and ammonia emission from fattening pigs.

Livestock Prod. Sci., 91(1-2), 45-55. doi:http://dx.doi.org/10.1016/j.livprodsci.2004.06.013

Powers, W. (2009). Conserving nutrients during storage. Manure \$ense guide. East Lansing, Mich.: Michigan State Univ. Extension.

Powers, W., \& Angel, R. (2008). A review of the capacity for nutritional strategies to address environmental challenges in poultry production. Poultry Sci., 87(10), 1929-1938. doi:http://dx.doi.org/10.3382/ps.2008-00090

Powers, W., Zamzow, S., \& Kerr, B. J. (2007). Reduced crude protein effects on aerial emissions from swine. Appl. Eng. Agric., 23(4), 539-546. doi:http://dx.doi.org/10.13031/2013.23487

Predicala, B., Cortus, E. L., Lemay, S. P., \& Lague, C. (2007). Effectiveness of a manure scraper system for reducing concentrations of hydrogen sulfide and ammonia in a swine grower-finisher room. Trans. ASABE, 50(3), 999-1006. doi:http://dx.doi.org/10.13031/2013.23140

Predicala, B., Nemati, M., Stade, S., \& Lague, C. (2008). Control of $\mathrm{H}_{2} \mathrm{~S}$ emission from swine manure using Na-nitrite and Namolybdate. J. Hazardous Materials, 154(1-3), 300-309. doi:http://dx.doi.org/10.1016/j.jhazmat.2007.10.026

Rahman, S., \& Borhan, M. S. (2012). Typical odor mitigation technologies for swine production facilities: A review. J. Civil Environ. Eng., 2(4), 117. doi:http://dx.doi.org/10.4172/2165784X.1000117

Rahman, S., \& Newman, D. (2012). Odor, ammonia, and hydrogen sulfide concentration and emissions from two farrowinggestation swine operations in North Dakota. Appl. Eng. Agric., 28(1), 107-115. doi:http://dx.doi.org/10.13031/2013.41279

Rahman, S., DeSutter, T., \& Zhang, Q. (2011). Efficacy of a microbial additive in reducing odor, ammonia, and hydrogen sulfide emissions from farrowing-gestation swine operation. Agric. Eng. Intl.: CIGR J., 13(3), 1-9. 
Riskowski, G. L. (2003). Overview of methods to reduce odorant emissions from confinement swine buildings. Univ. Illinois Pork Industry Conf. Swine Odor and Manure Management.

Ritter, W. F. (1989). Odour control of livestock wastes: State-ofthe-art in North America. J. Agric. Eng. Res., 42(1), 51-62. doi:http://dx.doi.org/10.1016/0021-8634(89)90039-5

Rumsey, I. C., Aneja, V. P., \& Lonneman, W. A. (2012). Characterizing non-methane volatile organic compounds emissions from a swine concentrated animal feeding operation. tmospheric Environ., 47, 348-357. doi:http://dx.doi.org/10.1016/j.atmosenv.2011.10.055

Shah, S. B., \& Kolar, P. (2012). Evaluation of additive for reducing gaseous emissions from swine waste. Agric Eng Int: CIGR Journal. 14(2), 10-20.

Schiffman, S. S., Bennett, J. L., \& Raymer, J. H. (2001). Quantification of odors and odorants from swine operations in North Carolina. Agric. Forest Meteorol., 108(3), 213-240. doi:http://dx.doi.org/10.1016/S0168-1923(01)00239-8

Schmidt, D. R., Janni, K. A., \& Nicolai, R. E. (2004). Biofilter design information. BAE \#18. Univ. Minnesota, Dept. Biosystems and Agricultural Engineering.

Schneegurt, M. A., Weber, D. L., Ewing, S., \& Schur, H. B. (2005). Evaluating biostimulant effects in swine production facility wastewater. Pages 1-6 in Proc. State Sci. Anim. Manure Waste Manag. Symp., San Antonio, TX. Natl. Cent. Manure Waste Manag., Raleigh, NC.

Schulte, D. D., Koppolu, L., Koelsch, R. K., \& Billesbach, D. P. (2004). Odor footprint modeling for confinement animal feeding operations. Annual Wastewater Management Association, WEF/A\&WMA Odors and Air Emissions. Bellevue, Wash.: Water Environment Federation.

Sheridan, B., Curran, T., Dodd, V., \& Colligan, J. (2002). Biofiltration of odour and ammonia from a pig unit: A pilotscale study. Biosyst. Eng., 82(4), 441-453. doi:http://dx.doi.org/10.1006/bioe.2002.0083

Smith, D. R., Moore, P. A., Haggard, B. E., Maxwell, C. V., Daniel, T. C., VanDevander, K., \& Davis, M. E. (2004). Effect of aluminum chloride and dietary phytase on relative ammonia losses from swine manure. J. Animal Sci., 82(2), 605-611.

Starmans, D. A. J., \& van der Hoek, K. W. (2007). Ammonia, the Case of the Netherlands. Wageningen Academic Publ.

Stenglein, R. M., Clanton, C. J., Schmidt, D. R., Jacobson, L. D., \& Janni, K. A. (2011). Covers for mitigating odor and gas emissions in animal agriculture: An overview. Washington, D.C.: USDA Air Quality Education in Animal Agriculture. Retrieved from

http://www.extension.org/sites/default/files/Covers\%20overview $\% 20$ FINAL_1.pdf

Stevens, S. S. (1961). The psychophysics of sensory function. In W. A. Rosenblith (Ed.), Sensory Communication (pp. 1-33). Cambridge, Mass.: MIT Press.

Stowell, R. R., Koppolu, L., Schulte, D. D., \& Koelsch, R. K. (2005). Applications of using the odor footprint tool. In T. Brown-Brandl (Ed.), Proc. Seventh Intl. Livestock Environment Symp. (pp. 496-503). St. Joseph, Mich.: ASAE.

Strik, D. P. B. T. B., Domnanovich, A. M., \& Holubar, P. (2006). A $\mathrm{pH}$-based control of ammonia in biogas during anaerobic digestion of artificial pig manure and maize silage. Process Biochem, 414(6), 1235- 1238. doi:http://dx.doi.org/10.1016/j.procbio.2005.12.008

Sun, G., Guo, H., \& Peterson, J. (2010). Seasonal odor, ammonia, hydrogen sulfide, and carbon dioxide concentrations and emissions from swine grower-finisher rooms. J. Air Waste Mgmt. Assoc., 60(4), 471-480. doi:http://dx.doi.org/10.3155/1047-3289.60.4.471
Sun, Y., Clanton, C. J., Janni, K. A., \& Malzer, G. L. (2000). Sulfur and nitrogen balances in biofilters for odorous gas emission control. Trans. ASABE, 43(6), 1861-1875.

doi:http://dx.doi.org/10.13031/2013.3091

Sutton, A. L., Kephart, K. B., Verstegen, M. W. A., Canh, T. T., \& Hobbs, P. J. (1999). Potential for reduction of odours compounds in swine manure through diet modification. $J$. Animal Sci., 77, 430-439.

Svennerstedt, B. (1999). Drainage properties and ammonia emissions in slatted floor systems for animal buildings. J. Agric. Eng. Res., 72(1), 19-25. doi:http://dx.doi.org/10.1006/jaer.1998.0347

Swanson, W. J., \& Loehr, R. C. (1997). Biofiltration: Fundamentals, design and operations principles, and applications. J. Environ. Eng., 123(6), 538-546. doi:http://dx.doi.org/10.1061/(ASCE)07339372(1997)123:6(538)

Sweeten, J. M., Jacobson, L. D., Heber, A. J., Schmidt, D. R., Lorimor, J. C., Westerman, P. W., Miner, J. R., Zhang, R. H., Williams, C. M., \& Auvermann, B. W. (2001). Odor mitigation for concentrated animal feeding operations: White paper and recommendations. In J. M. Rice, D. F. Caldwell, \& F. J. Humenik, Animal Agriculture and the Environment: National Center for Manure and Animal Waste Management White Papers. St. Joseph, Mich.: ASAE.

Szögi, A. A., \& Vanotti, M. B. (2007). Abatement of ammonia emissions from swine lagoons Using polymer-enhanced solidliquid separation. Appl. Eng. Agric., 23(6), 837-845. doi:http://dx.doi.org/10.13031/2013.24053

Thorne, P. S., Ansley, A. C., \& Perry, S. S. (2009). Concentrations of bioaerosols, odors, and hydrogen sulfide inside and downwind from two types of swine livestock operations. $J$. Occupational Environ. Hygiene(6), 211-220. doi:http://dx.doi.org/10.1080/15459620902729184

Timmerman, M., Hoofs, A. I. J., \& van Wagenberg, A. V. (2003). Ammonia emission from four systems for group-housed sows. Proc. Swine Housing II Conf. (pp. 122-128). St. Joseph, Mich.: ASAE.

Turner, L. W., Cromwell, G. L., Bridges, T. C., Cater, S., \& Gates, R. S. (1996). Ammonia (NH3) emission from swine waste as influenced by diet manipulation. Proc. 1st Intl. Conf.Air Pollution from Agriculture (pp. 453-458). Kansas City, Mo.: Operations.

Tyndall, J. C. (2008). The use of vegetative environmental buffers for livestock and poultry odor management. Proc. Mitigating Air Emissions from Animal Feeding Operations Conf. Iowa State Univ. Extension.

Van der Peet-Schwering, C., \& Voermans, M. (1996). Effect of feeding and housing on the ammonia emission of growing and finishing pig facilities. Report No. 10. Rosmalen, The Netherlands: Exp. Pig Station.

Van Kempen, T., \& van Heugten, E. (2002). Reducing the nutrient excretion and odor of pigs through nutitional means. Ames, Iowa: MidWest Plan Service, Iowa State University.

VanderZaag, A. C., Gordon, R. J., Glass, V. M., \& Jamieson, R. C. (2008). Floating covers to reduce gas emissions from liquid manure storages: A review. Appl. Eng. Agric., 24(5), 657-671. doi:http://dx.doi.org/10.13031/2013.25273

Varel, V. H., \& Wells, J. E. (2007). Influence of thymol and a urease inhibitor on coliform bacteria, odor, urea, and methane from a swine production manure pit. J. Environ. Qual., 36(3), 773-779. doi:http://dx.doi.org/10.2134/jeq2006.0394

Velthof, G. L., Nelemans, J. A., Oenema, O., \& Kuikman, P. J. (200). Gaseous nitrogen and carbon losses from pig manure derived from different diets. J. Environ. Qual., 34(2), 698-706. doi:http://dx.doi.org/10.2134/jeq2005.0698 
Walker, J., Spence, P., Kimbrough, S., \& Robarge, W. (2008). Inferential model estimates of ammonia dry deposition in the vicinity of a swine production facility. Atmospheric Environ., 42(14), 3407-3418. doi:http://dx.doi.org/10.1016/j.atmosenv.2007.06.004

Walker, P. M., \& Wade, C. A. (2009). Comparison of the effectiveness and economic costs of two production scale polyacrylamide assisted solid/liquid separation systems for the treatment of liquid swine manure. Appl. Eng. Agric., 26(2), 299305. doi:http://dx.doi.org/10.13031/2013.29545

Walter, D. (2010). Vegetative environmental buffers: New technology benefitting livestock farmers. Green Horizons, 14(3), 3.

Xue, S. K., Chen, S., \& Hermanson, R. E. (1999). Wheat straw cover for reducing ammonia and hydrogen sulfide emissions from dairy manure storage. Trans. ASAE, 42(4), 1095-1101. doi:http://dx.doi.org/10.13031/2013.13257

Ye, F. X., Zhu, R. F., \& Li, Y. (2009). Deodorization of swine manure slurry using horseradish and peroxides. J. Hazardous Materials, 167(1-3), 148-153. doi:http://dx.doi.org/10.1016/j.jhazmat.2008.12.096

Yoon, S. Y., Yang, Y. X., Shinde, P. L., Choi, J. Y., Kim, J. S., Kim, Y. W., Yun, K., Yo, J. K., Lee, J. H., Ohh, S. J., Kwon, I. K., \& Chae, B. J. (2010). Effects of mannanase and distillers dried grain with solubles on growth performance, nutrient digestibility, and carcass characteristics of grower-finisher pigs. J. Animal Sci., 88(1), 181-191. doi:http://dx.doi.org/10.2527/jas.2008-1741

Zahn, J. A., Hatfield, J. L., Do, Y. S., DiSpirito, A. A., Laird, D. A., \& Pfeiffer, R. L. (1997). Characterization of volatile organic emissions and wastes from a swine production facility. $J$. Environ. Quality, 26(6), 1687-1696. doi:http://dx.doi.org/10.2134/jeq1997.00472425002600060032x

Zahn, J. A., Tung, A. E., Roberts, B. A., \& Hatfield, J. L. (2001a). Abatement of ammonia and hydrogen sulfide emissions from a swine lagoon using a polymer biocover. J. Air Waste Mgmt. Assoc., 51(4), 562-573. doi:http://dx.doi.org/10.1080/10473289.2001.10464295
Zahn, J. A., J. L. Hatfield, J. L., Laird, D. A., Hart, T. T., Do, Y. S., \& DiSpirito, A. A. (2001b). Functional classification of swine manure management systems based on effluent and gas emission characteristics. J. Environ. Qualit, 30(2), 635-647. doi:http://dx.doi.org/10.2134/jeq2001.302635x

Zhang, Q., Feddes, J., Edeogu, I., Nyachoti, M., House, J., Small, D., Liu, C., Mann, D., \& Clark, G. (2002). Odour production, evaluation, and control. Final report project MLMMI 02-HERS03. Manitoba Livestock Manure Management Initiative Inc.

Zhang, Y. (1997). Sprinkling oil to remove dust, odor, and gases in swine buildings-AED 42. Ames, Iowa: Midwest Plan Service, Iowa State Univ.

Zhang, Y., \& Gaakeer, W. (1998). An inflatable cover for a concrete manure storage in a swine facility. App. Eng. Agric. 14(5), 557-561.

Zhao, L., Rausch, J. N., \& Combs, T. L. (2007). Odor control for land application of manure. Fact Sheet. Ohio State Univ. Extension.

Zhao, Y., Aarnink, A. J. A., de Jong, M. C. M., Ogink, N. W. M,, \& Groot Koerkamp, P. W. G.(2011). Effectiveness of multi-stage scrubbers in reducing emisions of air pollutants from pig houses. Trans. ASABE, 54(1), 285-293. doi:http://dx.doi.org/10.13031/2013.36256

Zhu, J. (2000). A review of microbiology in swine manure odor control. Agric. Ecosyst. Environ., 78(2), 93-106. doi:http://dx.doi.org/10.1016/S0167-8809(99)00116-4

Zhu, J., Bundy, D. S., Li, X., \& Rashid, N. (1997). Controlling odor and volatile substances in liquid hog manure by amendment. $J$. Environ. Qual., 26(3), 740-743. doi:http://dx.doi.org/10.2134/jeq1997.00472425002600030020x

Zhu, J., Ndegwa, P. M., \& Luo, A. (2000). Changes in swine manure solids during storage may affect separation efficiency. Appl. Eng. Agric., 16(5), 571-575. doi:http://dx.doi.org/10.13031/2013.5300 